This item was submitted to Loughborough's Research Repository by the author.

Items in Figshare are protected by copyright, with all rights reserved, unless otherwise indicated.

\title{
Future local passenger transport system scenarios and implications for policy and practice
}

PLEASE CITE THE PUBLISHED VERSION

https://doi.org/10.1016/j.tranpol.2020.02.009

PUBLISHER

Elsevier

VERSION

AM (Accepted Manuscript)

PUBLISHER STATEMENT

This paper was accepted for publication in the journal Transport Policy and the definitive published version is available at https://doi.org/10.1016/j.tranpol.2020.02.009.

LICENCE

CC BY-NC-ND 4.0

\section{REPOSITORY RECORD}

Enoch, Marcus, Richard Cross, Nick Potter, Cody Davdison, Sharnae Taylor, Russell Brown, Helen Huang, et al.. 2020. "Future Local Passenger Transport System Scenarios and Implications for Policy and Practice". Loughborough University. https://hdl.handle.net/2134/11887797.v1. 


\section{Future local passenger transport system scenarios and implications}

for policy and practice

Enoch $M \mathrm{P}^{* 1}$, Cross $\mathrm{R}^{2}$, Potter $\mathrm{N}^{2}$, Davidson $\mathrm{C}^{2}$, Taylor $\mathrm{S}^{2}$, Brown $\mathrm{R}^{2}$, Huang $\mathrm{H}^{2}$, Parsons $\mathrm{J}^{2}$, Tucker $\mathrm{S}^{2}$, Wynne $E^{2}$, Grieg $D^{2}$, Campbell $G^{2}$, Jackson $A^{3}$ and Potter $S^{4}$

${ }^{1}$ School of Architecture, Building and Civil Engineering, Loughborough University, Leicestershire LE11 3TU, UK.

${ }^{2}$ Ministry of Transport, 3 Queens Wharf, Wellington 6011, New Zealand.

${ }^{3}$ Victoria University of Wellington, PO Box 600, Wellington 6140, New Zealand.

${ }^{4}$ Department of Engineering and Innovation, Faculty of Mathematics, Computing and Technology, The Open University, Walton Hall, Milton Keynes MK7 6AA, UK.

*Corresponding author: Tel: +44 (0)1509 23408; Email: m.p.enoch@lboro.ac.uk. ORCID is https://orcid.org/0000-0002-9027-5459.

\section{Declaration of Interest Statement}

Professor Marcus Enoch was employed on a contractual basis to the New Zealand Ministry of Transport - the project sponsors - whilst undertaking this study through the Public Transport 2045 project. The other co-authors are/were full-time staff for the same organisation. There are no other potential conflict areas of interest.

\section{Acknowledgements}

This paper is derived from data collected through the Public Transport 2045 study which was funded and conducted by the New Zealand Ministry of Transport in conjunction with Professor Marcus Enoch of Loughborough University, who was employed as a strategy director on the project. Thanks are also due to the interviewees and workshop participants who gave up their time and expertise to help us with this study. Finally, we should like to dedicate this article to the memory of team member Josh Parsons, who died in April 2017 aged 44. 


\title{
Future local passenger transport system scenarios and implications for policy and practice
}

\author{
Abstract \\ The world is rapidly changing and the future is uncertain, yet until recently the dominant assumption \\ of the local passenger transport community has been that the existing modal landscape of cars, \\ buses and taxis will remain much as it is now. Such a view is now shifting however, with decision \\ makers now appreciating the need to understand the implications of potentially radical changes in \\ the technological, political, economic, social and environmental spheres. Accordingly, in August 2015 \\ the Public Transport 2045 study was commissioned to consider how different local public transport \\ futures might affect society over the next 30-years, and at how governments might best respond. \\ The multi-phase study was based on individual in-depth interviews with 50 senior local passenger \\ transport operators, government officials, lobbyists and experts from New Zealand and around the \\ world; and four validation workshops with 28 sector stakeholders. The data was analysed using \\ mostly pre-determined themes from which four scenarios were constructed and then validated. The \\ implications are that the transport system is about to transition to a system of 'shared mobility'; \\ public transport will need to evolve to stay relevant but will remain important in any scenario; and \\ the role of Government will be vital in overseeing the transition to the shared mobility era. These \\ lessons are now being used to inform transport and broader policy decisions across New Zealand. \\ Overall, the study is the first to apply such a global and qualitatively rich dataset to view the long- \\ term future passenger transport system as a whole.
}

Keywords: autonomous vehicle systems, planning and operational scenarios, local public transport policy futures, mobility-as-a-service (MaaS), integrated transit networks,

\section{Highlights}

- $\quad$ Considers passenger transport development over 30-years and Government response.

- 50 interviews, 4 validation workshops (28 stakeholders) led to 4 future scenarios.

- $\quad$ Public transport must evolve in transition to shared mobility future

- Government has key function in overseeing the transition.

- $\quad$ First large-scale, qualitative, long-term, global, holistic public transport study.

\section{Introduction}

Much has been written about the accelerating pace of societal and technological change, but, until recently, such statements have not typically been applied to the public transport sector. Indeed, the operational concept underlying the bus for instance (i.e. large vehicles on fixed routes and operating on fixed timetables) has not fundamentally changed as a concept since its introduction almost 200 
years ago (Agarwal et al, 2019; Vuchic, 2007, Potter et al, 2019). There is however growing evidence that this perspective is now beginning to change, with several recent reports serving to emphasise the need to understand the changing mobility landscape and the implications for the public transport sector. Thus, the UK government policy paper, The Future of Mobility (GOfS 2019) proclaimed this to be "a time of unprecedented change in the transport system", whilst KPMG's Mobility 2030 study reported that technological innovation will "completely disrupt" the mobility ecosystem within a decade (KPMG, 2019).

In response to this situation, in August 2015 the New Zealand Ministry of Transport (NZMOT) commissioned the Public Transport 2045 (PT2045) study to consider how different local public transport futures might affect society over a 30-year time horizon, and at how governments might best respond to secure the 'best' outcomes possible. The latter aim reflects the strong influence that transport systems have on the liveability of cities. A role for policy makers at a time of technological and behavioural transition is to envision the types of places that their citizens can live in and to shape the urban transport systems involved. The purpose of this paper is to present the results of this study.

\section{Previous work}

There is a significant body of work that examines how the various components of public transport systems may evolve in the future. On the supply side, smart infrastructure systems (e.g. FernándezIsabel et al, 2020); potential propulsion systems (Corrazza et al, 2016; Hua et al, 2014); guidance and control functions (Bansal and Kockelman, 2017; Fagnant and Kockelman, 2014; Villagra et al, 2012); and several other areas of study such as enhanced timetabling and routeing (Gecchelin and Webb, 2019; CRIUMS, 2016); improved passenger information (Nelson and Mulley, 2013); new modes (Cramer and Krueger, 2016; Shaheen et al, 2016; CRIUMS, 2016); Mobility as a Service and Mobility on Demand services (Sochor et al, 2017; Jittrapirom et al, 2018; Shaheen et al 2017); fare collection systems (Olivkova, 2017); and the huge growth in data (Milne and Watling, 2018; CRIUMS, 2016); now elicit significant research effort.

Similarly on the demand side demographic factors such as the effects of income, age, gender, population size and urbanisation on travel behaviour are well covered (e.g. FHWA, 2016; Dargay et al, 2007, Shergold et al, 2015; Stokes 2013; Delbosc and Currie, 2013; Scheiner, 2014; Newman and Kenworthy, 2011; Ingvardson and Nielsen, 2018; Potter et al, 2019); as are changing societal trends such as the sharing economy and attitudes to privacy (Hamari et al, 2016; Cruikshanks and Waterson, 2012); and shifting market niches due to new modes and changing customer preferences (Shaheen and Cohen, 2013; Smith et al, 2018; Durand et al, 2018; Sakaria and Stehfast 2013).

Lastly, there is some evidence now being compiled on the public policy, governance and regulatory aspects of future public transport futures (e.g. Cohen and Shaheen, 2016; Shaheen at al, 2016; Docherty et al, 2018; Enoch and Potter, 2016).

Previous work exploring possible futures of the overall passenger transport system are, however, limited. Thus, Shaheen et al (2018) consulted with an advisory committee of more than 50 local government officers in California to explore the likely development of an expanded list of 20 topics around how transportation might look in 2050, but presents no overall synthesis of how these factors may fit together. Meanwhile Shaheen and Cohen (2018) identified five core trends that 
might presage a public transit 'renaissance' i.e. changing generational behaviour toward suburbanisation and automobility; new attitudes toward information communications technology; shifting attitudes toward sharing and mobility on demand; new alternatives to work and non-work travel; and increasing number of on-demand flexible route transportation options.

Taking a different approach, Enoch (2015) proposed that the traditional local modes of car, bus and taxi might steadily converge into a single 'dial-a-pod' universal taxi system, while Edelenbosch et al (2017) used Integrated Assessment Models to explore the effect of different potential public transport futures on energy use and carbon dioxide levels. Julsrud and Priya Uteng (2015) devised three public transport visions - "Controlled mobility", "Technopolis" and "Shared mobility" - to explore how best to meet the demands for more efficient and environmentally friendly transport for Norway in 2050. Similarly, Hannon et al (2016) presented three visions of advanced integrated urban mobility for 2030 based firstly on key mobility trends (electrification, shared mobility and autonomy), and secondly on continued urbanisation. These are: 1) Clean and Shared, where rapidly growing but spatially constrained cities with terrible congestion and air quality currently such as Delhi and Mexico City opt to restrict car ownership and promote EVs. 2) Private autonomy: for sprawling cities such as Los Angeles, cars would remain essential for mobility but automation, EVs and sharing would help to mitigate the impacts. 3) Seamless Mobility: cities like London and Chicago would see door-to-door, on-demand services predominate, supported by a highly efficient public transport backbone, and enabled by smart software platforms. Angelidou et al (2017) estimated public transport demand in European cities ten years hence in light of changing market and societal trends such as the shared economy, more sustainable lifestyles, technological ubiquity and individual empowerment.

The GOfS policy paper The Future of Mobility (GOfS 2019) outlined four mobility scenarios for the UK in 2040 - "Trends Unmodified", "Technology Unleashed", "Individual Freedoms" and "Greener Communities" - whilst Stephenson et al (2018) concluded that New Zealand needed to adopt a more coherent and integrated approach to sustainability and fundamentally change its regulatory and funding environment. Canitez (2019) studied urban mobility futures for Istanbul, while Zmud et al (2013) compiled two future mobility scenarios for the USA: one where oil prices are higher, environmental regulations stricter and road fees are imposed (and hence vehicle miles travelled (VMT) fall), and one where no real changes occur with respect to oil prices, environmental regulations and road fees (and VMT rises). Finally, Spickermann et al (2014) presents a series of multi-modal scenarios for future city mobility in Germany, and Agarwal et al (2019) developed an interesting and comprehensive think piece as to what the urban transport system might look like in the future.

Only a few studies have therefore sought to take a strategic perspective of the long-term future of the local passenger transport system space, and none of these have taken an in-depth qualitative approach that draws on the views a wide range of international stakeholders. Hence such an approach became the focus of a study commissioned in late 2015 by the New Zealand Ministry of Transport.

\section{Methodology}

In a sector where the context is as highly complex as it is for passenger transport and where substantial technological, economic and behavioural change is beginning to emerge any single 
forecast or predictive methodology would be inappropriate. This study therefore adopted a scenario approach to identify and examine likely critical factors and to present a series of possible futures. The scenario development included stakeholder interviews, and the scenarios were then used to explore with these stakeholders the implications involved.

\subsection{Research design}

Table 1 presents the overall research design of the multi-phase project which links the project objectives with the methods used to address them.

\begin{tabular}{|l|l|}
\hline Objective & Method \\
\hline $\begin{array}{l}\text { To identify factors likely to influence the long- } \\
\text { term development of local passenger transport } \\
\text { systems. }\end{array}$ & $\begin{array}{l}\text { Literature Review and commissioned } \\
\text { Foundation Reports. }\end{array}$ \\
\hline $\begin{array}{l}\text { To examine possible long-term local passenger } \\
\text { transport futures. }\end{array}$ & $\begin{array}{l}\text { In-depth structured interviews with senior } \\
\text { public transport practitioners and experts. }\end{array}$ \\
\hline $\begin{array}{l}\text { To develop plausible and consistent long-term } \\
\text { future local passenger transport scenarios. }\end{array}$ & Team workshops. \\
\hline $\begin{array}{l}\text { To validate the future scenarios and explore } \\
\text { arising implications for policy and practice. }\end{array}$ & $\begin{array}{l}\text { Expert validation workshops and modelling } \\
\text { exercise }\end{array}$ \\
\hline $\begin{array}{l}\text { To make recommendations for policy makers } \\
\text { and practitioners in the local passenger } \\
\text { transport and related areas. }\end{array}$ & Expert validation workshops \\
\hline
\end{tabular}

Table 1: Research design

\subsection{Individual in-depth interviews with public transport experts}

The following questions were developed from a series of commissioned foundation reports and the literature review, coupled with some insights from the framework used by Vuchic (2007) for characterising the various elements of public transport systems.

\section{The future local transport system}

1. What do you think the local passenger transport system will look like in 2045? (please consider the whole transport system, including private vehicles, active modes, as well as public and passenger transport).

2. What sort of public/passenger transport will be available in 2045 ?

3. What will public/passenger transport vehicles look like in 2045 , and how might they be configured?

4. What will the supporting infrastructure look like in 2045?

5. How will users interface with the transport system in 2045?

\section{Demand characteristics and public/passenger transport markets}

6. Who will be using public/passenger transport in 2045?

7. How will passenger needs and expectations change in the future, and how will these aspects influence the design of public and passenger transport services in 2045?

\section{Stakeholder roles}

8. What types of operator will deliver public/passenger transport services in 2045 ?

9. How might the roles of local and central government be different in 2045 ?

\section{Drivers of change}

10. What key factors do you see driving these changes over the next 30 years, and briefly explain how you see these factors influencing future public transport service configurations.

Table 2: Standardised interview template 
These questions formed a basis for a standardised interview template (see Table 2), which NZMOT officials piloted. Questions were asked using question cards, whereby the role of the interviewer is to guide the interviewee from question to question with minimal interaction to reduce any bias in the responses as far as possible (Miles and Huberman, 1994).

Fifty candidates from New Zealand (35), the UK (11), the USA (3) and Australia (1) were interviewed. Members of the study team identified and selected the interviewees from the literature review and from personal knowledge of their expertise. Specifically, a purposive sampling technique was adopted whereby potential candidates were discussed by members of the study team, and those who met the agreed level of expertise in either the public transport sector or else in an appropriate related topic area were selected. This approach was supplemented by a 'snowballing' technique whereby interviewees suggested further appropriate experts, whom were then once again discussed in team meetings to ensure they were appropriate (Miles and Huberman, 1994). 'Experts' in this sense can be defined as being: 'individuals with specialised knowledge in a specific field with demonstrated experience and involvement which is of particular to a specific study' (Gläser and Laudel, 2004). The roles of these experts included government officials (16 national and 4 local); transport operators ( 2 public transport, 3 from so-called new modes and 1 equipment provider from a related sector); lobbyists ( 3 for public transport and 5 for transport and related areas more generally), and industry observers (12 university academics, 3 consultants and 1 journalist). Overall, 14 of the international interviewees were industry observers and 1 was a private operator. Most (43) of the interviewees were male, with seven being women. Table 3 provides details of those interviewed.

\section{INSERT TABLE 3 HERE}

\section{Table 3: Interviewee details}

The square bracketed numbers refer to the interviewee ID which will be cited at several points in the text of this article.

Twenty-nine interviews were conducted face to face, and 21 by skype or telephone, whilst 35 were conducted by two members of the study team, and the remainder by a single interviewer. Interviewees were sent a copy of the questions in advance to allow them the opportunity to prepare answers. The interviews were recorded, and each took between 30 and 75 minutes. They were conducted between mid-February and the end of March 2016. Data were transcribed manually and anonymised by assigning a unique identifier to each transcript, and the resultant meanings were condensed and categorised, mostly in line with the questions asked to help generate themes and suthemes (Kvale, 1996). This process was also done manually, and involved reading through the data, noting initial thoughts, and then systematically allocating the data to the most relevant thematic sections. Next, the data were reviewed and organised into a narrative to reveal relationships, complexities and connections (Boyzatis, 1998; Braun and Clarke, 2006). All statements reported were made anonymous. At this point it should be noted that not every interviewee answered every question, and that in some cases interviewees provided more than one (sometimes apparently contradictory) statements.

\subsection{Scenario planning}

On completion of the initial analysis, the scenario planning phase began. A scenario is a representation of a potential or supposed situation (Bood and Postma 1997) and can be useful 
because they draw on an analysis of the likely critical uncertainties to present a series of pictures of possible (and hopefully plausible) futures to provide a neutral space that allows different stakeholders to discuss the issues raised in a safe environment (Van der Heijden, 2005; Linz, 2012). It is important to recognise scenarios do not predict or forecast the future, but they can help, if done properly, to give advance warning of potential challenges and opportunities.

The process of establishing the preliminary scenarios was undertaken during a number of PT2045 team meetings conducted over an intensive two-week period in March 2016. Given the importance attached by NZMOT to the relationship between transport and the liveability of cities, care was taken to ensure that each scenario was very descriptive in encouraging people to imagine what urban life in a country such as New Zealand could look like in the future.

The first step involved identifying the key factors which formed the dimensions of a series of preliminary scenarios. Various possible options were considered based on an initial reading of the interview findings, with the 'most interesting' felt to relate to the future population density (a demand-oriented variable) and the level of transport system automation (supply-oriented).

For the second step, a series of 'future world contexts' were developed for each scenario. Crucially, these included a narrative on how the world of 2016 evolved into that particular context in 2045 to help ensure some sense of 'believability', and effectively set the conditions in which future transport systems would need to develop and operate.

Step three involved the team discussing the transport systems potentially likely to inhabit each of these contexts; and then more closely defining what a plausible transport system would look like. Once again, a narrative device was used to help make the scenarios as credible as possible.

Finally, in step four three of these preliminary scenarios were discussed in detail at four two-hour workshops - A (with 7 transport operators) and B (with 7 members of the Auckland Transport Alignment Project) in Auckland on 7 April 2016, and two C (with 6 representatives from Government agencies) and $\mathrm{D}$ (with 8 Wellington transport operators and other stakeholders) in Wellington on 12 April 2016 - with feedback used to help develop the final scenarios in a form of validation exercise. Of these 28 attendees, half had not been interviewed previously. Comments were requested about whether the scenarios were understandable, plausible, robust, consistent and comprehensive; and about how each of the scenarios might perform in practice.

Outputs from the workshops were then also used to provide a (necessarily crude) indication as to the transport and societal costs and benefits of each scenario should they occur in practice, and these are presented with the detailed scenario results in NZMOT (2018).

\section{Findings}

\subsection{Future of local transport}

From a travel demand perspective, six interviewees saw more opportunities for increasing travel emerging, whilst three saw less need for travel. Twelve interviewees envisaged demand becoming more dispersed in spatial and/or temporal dimensions. There were no real differences between interviewee backgrounds (see Supplementary Table 1). 
On the supply side, fully 45 interviewees explicitly stated that the transport system would look similar to now, with interviewee [1] anticipating people "still moving in metal boxes", whilst five (four international industry observers and a 'new mode' operator) did not express an opinion. In terms of the range of modes, seven interviewees thought these would diverge, five expected no change, and three felt that transport modes would converge. Four interviewees ( 3 observers and a lobbyist) expected some form of 'dial-a-pod' (shared autonomous taxi) system would dominate by 2045. There were no clear differences by stakeholder type (Supplementary Table 2).

Vehicle ownership expectations were that 28 interviewees from all stakeholder groups expecting this to fall over time, with four international observers and one public transport lobbyist believing that vehicle ownership would remain about the same. By contrast, only two felt that vehicle ownership would increase by 2045 , and seven interviewees were unsure (Table 4).

\section{INSERT TABLE 4 HERE}

\section{Table 4: Vehicle ownership expectations by interviewee type}

Trips by active modes (walk and cycle) were anticipated to increase in importance by eight interviewees of whom four were international observers; nine interviewees (five from national government) expected them to remain at a similar level to now. Of these 17 interviewees, four were women - a higher ratio than for any other question. Only two interviewees (both international observers) saw active modes declining (Supplementary Table 3).

So-called 'small transport' modes (segways, electric bicycles, hoverboards, scooters) were expected to increase in importance by twelve interviewees (four national government employees and four international observers), and four interviewees mentioned the possibility of flying cars or people drones (Supplementary Table 3).

The trend towards autonomous vehicles (AVs) was another important theme. Altogether, 36 interviewees of 42 who expressed an opinion expected to see at least some AVs being used by 2045 (of whom 26 said "definitely", and ten "probably"). Two interviewees said mass transit definitely would not require drivers whilst interviewee [48] believed that "the transport system would not wholly comprise AVs". In terms of the effect of AVs, 17 suggested that automated driving represented the "biggest opportunity for public transport", though [4] said AVs were "not so important" and interviewee [7] believed that "AVs would have only a minor impact". Of the six who felt that AVs would not be adopted by 2045, one, [40] anticipated that "many vehicles would be semi-autonomous" (Supplementary Table 4).

Another interviewee mentioned that "the roads would become much safer" by 2045 [1], three set out important objectives to be met as being the environment, health, cost and time saving, and one believed that "the transport system would be more customer focused" [47].

In connecting demand and supply, seven interviewees suggested the local transport system as a whole would become more sophisticated and data-informed, with five noting that this would involve being able to better match the demand for transport with the supply of transport perhaps through some form of mobility as a service arrangement. 
Perhaps most interesting was the continued dominance of the mobile metal box paradigm, coupled with expectations by many of the interviewees that car ownership would be less than currently and that Autonomous Vehicles would be operational within the timeframe.

\subsection{Local public transport in 2045}

Two dominant expectations for public transport in 2045 emerged from the interviews. The first was that 'conventional' public transport would still play an important role. Most strongly, 42 interviewees across the board expressed a view that mass transit would still operate on high density corridors. Interviewee [20] said corridors would form the key "building block approach to transit" and two others (interviewees [20] and [34]) felt corridors would become stronger. However, two others ([26] and [35]) anticipated the opposite, with one believing that only rail-based corridors would continue to exist. Interestingly, two of the three new mode operators, but only one international observer and two government officials were among the eight interviewees who disagreed with this view. However, it should also be noted that only ten interviewees out of the total of fifty believed that there would be little change in how public transport was delivered more generally. Forty of the interviewees expected some form of evolution to occur in the nature of public transport services. Seven of the ten who adopted a very cautious view of little structural change were international, and only one of the ten was a government official, which is perhaps contrary to what may have been expected at the outset.

This feeling of being on the cusp of change is the second dominant expectation. Thus, 38 interviewees considered that some form of demand responsive shuttle/jitney-type network would operate a much broader network in lower demand areas, ten interviewees expected a larger role for shared transport systems (five of whom were women), nine interviewees predicted a blending of shared private and mass public transport systems (four of whom were non-transport government officials), seven interviewees forecast a broader range of public transport modes (no international observers), and seven interviewees felt that buses in their current form would disappear (four international observers) (Table 5). Two representative quotes here were "lesser [bus] services on the fringes will wither away" (interviewee [17] and "I think buses as we see them today will be gone" (interviewee [26].

\section{INSERT TABLE 5 HERE}

\section{Table 5: Public transport futures by interviewee type}

Eight interviewees expected public transport to be smarter, more adaptive and more efficient and five interviewees suggested that public transport services would be more linked up. One other interviewee [16], noted that "mass transit would become far more personalised in future".

\subsection{Public transport vehicles}

It was striking that only seven out of the fifty interviewees from across the stakeholder groups said that vehicles used to provide public transport would be similar to today.

Considering future vehicle sizes, 34 interviewees expected to see a (wider) range, with [7] and [8] foreseeing an "explosion" in vehicle types and [45] and [46] subscribing to the view that varied fleets were needed because "one size does not fit all" market needs. These observations seem to tie in with the expectation of a broader range of public transport modes being available in future. 
Seventeen interviewees expected vehicles to become smaller, whilst three expected vehicles to become larger across the board, and four expected larger vehicles only for the higher density corridor services to accommodate more people and providing passengers with more space. There were no discernible differences between stakeholder groups. Meanwhile eight interviewees mentioned the concept of modular vehicles being used (Supplementary Table 5), and a further four noted that vehicles could be flexible, perhaps with "private cabins" [37], though a further two were sceptical that vehicle interiors would change dynamically. Four interviewees considered that vehicles will be governed more by what people want; [47] expected vehicles to of a "higher quality"; and [7] imagined there would be "special interiors".

Electricity ( 22 interviewees) is seen as the favoured power source of the future "assuming supply chain issues could be overcome" (interviewee [5]). Five additional interviewees felt this would be delivered by battery - though [1] "did not expect battery to be the answer" and [14] "was concerned that batteries remained a crucial barrier". By contrast, nine believed that a diverse range of propulsion technologies would be in place, whilst eight interviewees (none of whom were operators or women) suggested that hybrid solutions may be most appropriate (Supplementary Table 6). Internal combustion engines had two adherents, though [11] said "not ICE" and [46] offered "not carbon-based", with hydrogen having one advocate, [8] - these views were all expressed by the international observers.

\subsection{Public transport infrastructure}

Twenty-one interviewees imagined that the infrastructure for public transport would not much change compared to today, and four more suggested that rails would still exist due to legacy effects. Twenty suggested that roads would be equipped with sensors in future. Interviewees [4],[27] and [49] imagined infrastructure being "used more flexibly", with [5],[6] and [49] speculating that vehicles might be required to "book slots" on the infrastructure before using it.

Regarding modal segregation on the right of way, 18 interviewees believed this would increase and, whilst [8] agreed that it would increase "initially", three interviewees saw modes being "virtually segregated", three thought that modes would be "grade [i.e. vertically] separated", and seven saw no need for segregation if vehicles were automated in the future (Supplementary Table 7).

Almost half of the interviewees (23), expected vehicles to automatically steer themselves, whilst three mentioned that rail-based guidance systems would still be used, and [43] expected "vehicles to be guided by sensors in the road". By contrast interviewee [9] said vehicles would still be "steered by human drivers", and one [7] anticipated that "rural areas would still be fairly low-tech" (Supplementary Table 8).

Seven interviewees expected vehicles on the network to be fully controlled by the system and five thought that a partially automatically controlled system was more likely, whilst 14 interviewees imagined such systems to be driver monitored, and five mentioned the concept of vehicle-to-vehicle communication being important in enabling platoons to operate. Six interviewees expected the transport control system to be centralised, 14 felt there would be a mixed configuration, and five decentralised (Supplementary Table 8).

Broadly these various responses suggest there is little by way of consensus among these key actors on the strategic design of future public transport systems. Roughly half found it difficult to 
comprehend the possibilities of how digital technologies could change public transport systems or could only comprehend it as an incremental change. Those anticipating more radical changes differed greatly in what these might be.

\subsection{User interface}

Significant changes are expected regarding ticketing and pricing (Table 6):

- 39 interviewees foresaw ticketing in future as being low-friction. [1] and [3] mentioned "new payment methods" emerging, whilst two said bankcards were the future payment mechanism; [7] favoured a "biometric" solution and [5] said that tickets would be "forgotten" (though not specifying how).

- 38 interviewees saw pricing becoming far more differentiated by 2045 based either on the level of demand for the service (two interviewees) amount of carbon emitted (two interviewees), or the quality of the service offered (two interviewees).

The provision of passenger information was expected by the interviewees to change on a more incremental basis. Twenty-nine interviewees expected information to be mostly delivered by a handheld or equivalent personal device, with 15 suggesting that the transport system will tell the passenger how to travel. Traditional timetable displays were expected to disappear by 14 interviewees, whilst eleven interviewees expected they would be modified, and eleven expecting them to remain as now - note, three interviewees recorded answers in both the 'modified' and 'remain as now' categories (Table 8). One [12] felt that "timetables would be needed at stops for reassurance".

Information provision is one area where the digital world is already impinging on public transport, and these responses seem to reflect this.

\section{INSERT TABLE 6 HERE}

\section{Table 6: The user interface of the future by interviewee type}

Regarding the on-board experience, 13 interviewees imagined "personalised" or "create-your-own" environments on public transport vehicles, four said that "the space would be useful" [20],[22],[29],[47], and [5] speculated that public transport could be a "space to switch off". Four more interviewees however, saw only a "limited space for change" [11],[12],[37],[38]. Overall, nine interviewees expected the on-board experience to improve for the user. When asked how service patterns might evolve in future, 30 interviewees from across the range of stakeholder groups said that more routes would change to become more flexible rather than fixed and 28 interviewees said more services would operate on demand. Point-to-point services, i.e. where there was no need for travellers to interchange between services when travelling to a destination, were seen as predominating in the future by 20 interviewees whilst a further 15 proposed that point-to-point services would become increasingly important. The alternative configuration of hub-and-spoke operations, with the interchange forming a key component of the journey, was considered by 20 interviewees to be more important for 2045 than now, providing this design enhanced the flexibility to pick up and drop off people and that the overall speed of service was not compromised. Nine interviewees felt that hub-and-spoke services would evolve into different forms. Thus [36] saw "fewer but larger hubs", [47] imagined "activity-based hubs", [12] mentioned "hubs would need 
higher frequencies", and [4] highlighted the idea of hubs being "flexible and dynamic", in part because current hubs could be "problematic" in how they were operated [3]. Finally, twelve interviewees expected that journeys will be seamless. [6] mentioned that users would need to "book trips" in future, and [29] said that there would be "easier physical access to the public transport network" (see Table 7).

Again, the responses from the interviewees displayed a great diversity of views of how public transport services would evolve, with several non-compatible concepts attracting strong support.

\section{INSERT TABLE 7 HERE}

\section{Table 7: Future service delivery mechanisms by interviewee type}

\subsection{Public transport users of the future}

The interviewees anticipated more people using public transport with 20 interviewees expecting almost everybody to be travelling by public transport by 2045. In particular, 16 interviewees highlighted city dwellers as becoming more reliant on public transport. This was for several reasons. One was that exactly half (25) of the interviewees said that differentiation of the public transport product would increase, such that users would pay different fares for different attribute bundles and so make public transport far more tailored to the individual needs of people and so more attractive. A second was because of the blending of shared and mass transit phenomenon described earlier (four interviewees), a third was a perception that "public transport will have less of a stigma" $[10],[17],[34],[36]$, and a fourth that "attitudes to public transport were changing" in metropolitan areas, and amongst the young [45].

In strong contrast, 20 interviewees felt that public or mass transport would only be for less advantaged sections of society in future, particularly "poorer people" [12], children and young people (six interviewees), the elderly (seven interviewees), and those in rural areas (seven interviewees). They also thought there would be correspondingly higher vehicle ownership levels in the countryside and five interviewees, [18] and [19] expected less people to use mass transit in the future across the board. Interviewees [28] and [29] speculated that there would be less travel overall.

Taking a middle view, seven of the interviewees felt that public transport users would be similar to those currently (seven interviewees). One other observation was that peak travel is becoming less important, with both positive and negative implications for public transport use (two interviewees) (Supplementary Table 9).

Overall, there was considerable divergence on expectations among the interviewees, with views being somewhat polarised.

\subsection{Passenger needs and expectations}

Just over half of the interviewees (27) agreed that the expectations of public transport passengers will increase into the future, with [28] and [34] suggesting that passenger needs were "rapidly changing", whilst another five interviewees pointed out that they had "already shifted". Interviewee [19] emphasised that expectations would be "astronomically high" and [40] added that whilst "the needs [would be] the same, the expectations [would be] massively up". In contrast, five interviewees said needs and expectations would be similar to now, and [23] said "no one knows". More 
specifically, eleven interviewees imagined users expecting services to arrive almost instantly "people won't wait longer than five minutes for a pod to arrive" [2] and "I need it now and it will arrive" [31]. Interviewees also noted that users want the public transport system to deliver "end to end transport" (five), "provide greater choice" (three), be "far more personalised" (six) and "more customer centred" [17],[32],[35] and so be "more like a car/taxi" [49]. They added that public transport services will need to allow "effective use of time" [20],[43], be "more flexible" [20],[27],[35],[49], "faster" [36], "comfortable" [15],[35],[49], "100\% reliable" [1],[3],[29], "100\% safe" [3],[26], "secure" [15,[18], "enjoyable" [20], "clean" [15], "higher [better] quality" [11], "accessible to old people" [12],[29], and be "carbon minimal" [1] with "one stop payment" [1],[37], and to "never be late" [1],[49]. Interviewees [5] and [6] added that such demands will "need to be managed", whilst [13] and [16] said that passenger demands "would not be met". [2] agreed, noting that "cost pressures meant that there could be no major changes to the design of public transport even if expectations did [significantly change]".

More generally, [24] expected people to "travel more", whilst [48] felt people "would still need to travel", and [7] thought that video conferencing and deliveries would mean "people would travel less" and [25] proposed that people would seek to "minimise their transport" when travelling from place to place. Interviewees [5] and [15] speculated that people might want more opportunities to "interact with people", and a chance to "switch off". Interviewee [8] suggested that non-corridor public transport would need to be improved.

\subsection{The operational environment}

In considering the operational environment as a whole, 23 interviewees expected private operators to dominate the public transport market in the future. Within this, more involvement by very large global organisations such as Google, Amazon, Uber and major car manufacturers was regarded as being likely by eleven interviewees. In line with this, "large robot operators" [50], "finance companies" [36], and "vehicle fleet owners" [26],[46],[47] were mentioned as potentially becoming a part of the public transport sector, a view based on an idea that the industry would become increasingly complex and hence there was a need for "significant investment" to spread expertise and generate "sufficient economies of scale" [5],[7],[36].

Seven interviewees picked up a different theme, mentioning that smaller operators were likely to emerge, with five interviewees suggesting the prospect of neighbourhood/social/local or "community operators" [6],[11],[30],[35],[49], and three suggesting that "public sector operators" might still be important, particularly for socially necessary (non-commercially viable) services [15],[19],[30], and "employers" being mentioned by [11]. Interviewee [20] argued that new operators "more tuned into consumer preferences" were needed, [36] suggested that operators would need to be "more responsive" to threats and opportunities in future. Finally, there was a view that private infrastructure providers might "perhaps" play a role in the future marketplace [1].

Thirteen interviewees said the operational mix could well be highly complex and fragmented and [12] suggested that "the system could be a blend of large and small" operators, whilst [3] and [8] noted a "blurring of operator roles" occurring, and [45] commented that "new business models" were required. Eight interviewees expected brokers to become more important in the provision of public transport, whilst [29] noted that some form of "mobility authority" could well be one means of providing coordinated mobility services. Six interviewees mentioned "public private partnerships" 
developing, and [41] suggested that "more leasing companies" might well begin to work in the sector. Only eight interviewees (four of whom were national government transport officials and none of whom were international observers) foresaw "no major changes to the operational environment" [2],[4],[21],[22],[23],[32],[34],[41], of whom two saw no major changes to operational business models (see Table 8 ).

Once again, there is little consensus as to the operational environment as to what is likely to emerge.

\section{INSERT TABLE 8 HERE}

\section{Table 8: The future operational environment by interviewee type}

\subsection{The role of Government}

There were contrasting views about if and how the role of government would change in the provision and operation of public transport services. Seventeen interviewees saw the role of Government remaining as now, whilst seven saw a smaller role - [16] said "increasingly hands off". Only three saw Government becoming a more important player in public transport, and [8] suggested the role of Government would be "very different". Three interviewees felt that national government would become "more involved" than now [19],[26],[29], but two thought that there would be "more devolution" [6],[20]. As to the nature of the role of government, six interviewees suggested "Government would need to be more flexible" [5],[27],[28],[37],[39],[43] - [43] advised "keep your options open", five "more joined-up" [11],[30],[40],[41],[43] by being more integrated "with economic, trade, technical and planning departments" [11], and three "more proactive" [26],[39],[46] - [46] added that "[Government] needs to decide [its future role]". Interviewee [12] predicted that "Government would be using far more data for planning".

Discussing the functions of government in future in more detail, 20 interviewees mentioned regulation as being a key role in 2045, whilst one said "possibly" [4] and one "possibly not" [9]. Interviewees [7] and [3] felt "competition regulation" would be important, "privacy/data regulation" was highlighted by [3] and [4] and "safety regulation" was mentioned by [3]. [47] imagined that operational regulation would not be government controlled in future. Finally, [50] saw a "big change" in regulation, and [40] and [50] felt it would become "more complex".

Six interviewees anticipated that Government would continue to own infrastructure, two more thought they possibly would, while two others thought they probably would not. Regarding subsidy provision, six interviewees thought Government would continue to subsidise public transport services, one said possibly yes, three interviewees said they possibly would not, and three said they would not subsidise services. Two interviewees said that Government would subsidise users rather than services, four thought they might subsidise users, and one said they would not. Five interviewees mentioned that governments would focus on introducing "new policies" in future that related to public transport [3],[13],[45],[47],[48], and two more thought they possibly would do this. Interviewees were fairly evenly split on whether Governments would operate services in future, with four saying they would, and four saying they would not, though two additional interviewees thought they possibly would. Finally, five interviewees expected "Government to be facilitating partnerships" [8],[32],[33],[45],[49] (Supplementary Table 10), which represents a very different way to provide and develop public transport services to that at present. 
Overall, these responses indicate that the interviewees generally anticipate a change in the role of government and the way it intervenes in public transport, but there was a great divergence in views of how this might happen.

\subsection{External factors}

Several key drivers of change i.e. "societal megatrends" [11], were mentioned by those interviewed. Thirty-two interviewees mentioned technology as being important and of these, 13 mentioned autonomous vehicles, and ten noted the importance of the changing data landscape, whilst [10] and [40] pinpointed "virtual reality", [24] said "sensor technology", [44] thought "3D printing" and [50] focused on "robots". Interestingly, [4] and [12] saw "technology not as a driver, but as an enabler". Twenty-one interviewees mentioned climate change and the carbon agenda as a major influence on the evolution of public transport and 11 more mentioned environmental goals - though [40] said "not climate change". Fourteen interviewees mentioned political or institutional factors. Socioeconomic factors as a whole rated a mention by three interviewees. More specifically, 14 interviewees discussed changing travel patterns, twelve interviewees suggested lifestyle changes, twelve mentioned urbanisation, eleven argued that economic changes were key, ten mentioned population changes (e.g. immigration and ageing), nine highlighted the importance of energy charges and oil prices, two suggested "health outcomes", and [26] proposed "community". Finally, market-related drivers were mentioned by eight interviewees, along with comments on "individualisation" [9],[16],[47], "urban design" [1],[30],[45], the "sharing economy" [10],[12], and "network resilience" [4],[49].

In terms of the dominant barriers to change, legal and ethical concerns were mentioned by 15 interviewees, whilst "political resistance" was raised by five, as was the "lack of physical space". "Funding" was seen as problematic by [15],[36] and [46], as were "external shocks" [6],[23] such as "nasty crashes, terrorism or data breeches" [3], whilst others included "international trade rules" [4],[30], "infrastructure" [14], "data infrastructure" [48], "public opinion" [9]. Lastly, three barriers were mentioned which related to the uptake of autonomous vehicles, namely: "technical barriers" [14], "love of cars" [6] and the need to find appropriate "business models for AVs" [1] (Supplementary Table 11).

\subsection{Transition to the future}

Eight interviewees felt that the transition to a new public transport and/or autonomous vehicle future is likely to be slow, with "full evolution" taking up to 30 years [20], due to legacy effects of "15 years for buses and 30 years for rail" [12]. Similarly, transition will be "uncertain" [34], "messy" [3],[45],[49], "volatile" [44], and will take place for different aspects at a "mixed speed" [4].

Nine interviewees (five international observers and four national government transport officials) felt that public transport would be an early adopter of AV technology, three interviewees felt that AVs would first be adopted by car fleet owners, and one by farm vehicles [50]. Interviewee [46] proposed that transition would be "Government-guided", whilst [5] thought "urban transport systems" and [7] and [49] that "niche corridors and/or areas" would be the first sites to change. The opportunity to retrofit manually driven vehicles to become autonomous was mentioned by [23] (Supplementary Table 12). 


\section{Discussion}

Perhaps unsurprisingly, 45 of the 50 interviewees explicitly stated that the future local transport system would still comprise of people moving around in metal boxes. More interesting, was that just over half of interviewees (28) expected vehicle ownership to fall over time (only two thought it would increase). This would be a highly significant change given that car ownership levels have historically steadily climbed in every world region for decades, with a global increase in vehicles of use of $27 \%$ between 2005 and 2015 to a rate of 182 vehicles per 1000 people (International Organization of Motor Vehicle Manufacturers, 2015). It is also a rather different expectation to results from the 'traditional' academic literature. Thus Sperling and Gordon (2009) point out that currently 85 per cent of the world's population does not own a car but that the majority aspire to do so, and so predicts that car use will continue to grow by three per cent a year so that by 2020 there would be two billion vehicles globally, at least half of which will be cars. In actual fact, as of 2019 the total was 1.5 billion (Wang, 2019). In contrast, Dargay et al, (2007) sees vehicle ownership levels effectively stabilising, and therefore presumably derives from some sort of expected major change in how transport is provided. Some publications support a similar view to the interviewees, with Arbib and Seba (2017) proposing that private car ownership will drop by $80 \%$ between 2020 and 2030 in the US, i.e. from 247 million to only 44 million.

The result that 36 interviewees thought Autonomous Vehicles would definitely or probably exist by 2045 compared with six that were unconvinced, largely chimes with evidence in Bansal and Kockelman (2017), which reported a take up of (level 4) AVs of between $24 \%$ and $87 \%$ of the U.S. vehicle fleet by 2045 , and Hannon et al (2016) which speculated that $40 \%$ of the vehicle fleet could be driverless by 2030 .

In terms of future local public transport, 42 interviewees expected that mass transit would still operate on high density corridors in future - with the legacy effects of railways in particular playing an influence here, and this does tie in with evidence such as Hannon et al (2016), which in one scenario saw public transport as the 'backbone' to a seamless mobility future. More interestingly, 38 felt some form of demand responsive shuttle/jitney-type network would operate a much broader network in lower demand areas as proposed for example in CRIUMS (2016), presumably supported thanks to the availability of driverless technology (Agarwal et al, 2019) and the changing nature of travel demand (Potter et al, 2019; Sakaria and Stehfest, 2013). Relating this to the vehicles to be used, 34 interviewees expected to see a (wider) range of vehicle sizes, and 17 interviewees expected vehicles to become smaller (CRIUMS, 2016) - a factor that may have been related to the growth in DRT-type networks mentioned along with the expected uptake of AVs (Gecchelin and Webb, 2019). Twenty-seven interviewees expected vehicles to be powered by electricity in some form as suggested in Hannon et al (2016) and Shaheen et al (2018) - a result which was obtained before the most recent concerns regarding the damaging health impacts of diesel-powered vehicles emerged, and which could be expected to make such a change even more likely (Webb, 2019). Maybe more interesting were the predictions about future infrastructure. Here 21 interviewees imagined that the infrastructure for public transport would be similar to today, whilst 20 proposed that roads would be substantially equipped with sensors in future (as described in Fernández-Isabel et al, 2020) - findings that suggest an even split between those who expect a transport system whereby vehicles operate as individual agents, and those who imagine a centrally-applied 'control infrastructure'-based system to manage mobility across the network. Almost half of the interviewees (23) explicitly stated that 
public transport vehicles would automatically steer themselves - a figure that seems quite low when compared to the expected level of AV take-up.

Thoughts on how users might engage with future public transport were in some respects more homogenous, with 39 interviewees foreseeing ticketing as low-friction, and 38 interviewees saw pricing becoming far more differentiated by 2045 - both of which are now beginning to be implemented on an experimental basis (see Olivkova, 2016). Twenty-nine interviewees expected information to be mostly delivered by a hand-held or equivalent personal device, again a process that is already well underway (see Nelson and Mulley, 2013). Thirty interviewees said that more routes would change to become more flexible rather than fixed, of whom 28 said more services would operate on demand - a shift facilitated by better data and by the expected take-up of AVs - a conclusion also arrived at by Gecchelin and Webb (2019). No common view was expressed as to whether point-to-point or hub-and-spoke services would dominate in future, with each position being supported by 20 interviewees. By contrast, there was no agreement as to the future user-base of public transport, with 20 interviewees predicting that almost everyone would be travelling to some extent by public transport by 2045 but 20 others feeling that public or mass transport would only be for those without car access. More consensus was achieved over the idea that the expectations of public transport passengers will increase in the future (27 interviewees) - a point also reflected in the literature with the shift towards shared transport modes in particular (e.g. in Shaheen and Cohen, 2013; Smith et al, 2018; and Durand et al, 2018).

Just under half of the interviewees (23) expected private operators to dominate the future public transport market, which suggests a degree of uncertainty as to the future operational environment. Meanwhile 17 interviewees saw the role of Government remaining as now and 20 interviewees mentioned regulation as being a key role in 2045, so apparently only minor changes expected in this regard - a position not wholly in agreement with the extant literature (Docherty et al, 2018; Enoch and Potter, 2016; Shaheen et al, 2016), which tends to suggest that some institutional change will likely be required.

Finally, 32 interviewees mentioned technology as being the most important external influences on future public transport development, while 21 mentioned climate change and the carbon agenda, both of which tally with factors noted in the literature (e.g. Fagnant and Kockelman, 2014; Villagra et al, 2012; Milne and Watling, 2018; Edelenbosch et al, 2017; Julsrud and Priya Uteng, 2015; Angelidou et al, 2017).

Arising from these observations, perhaps the major theme is the presence of two somewhat polarised perspectives, between the incrementalist or conservative camp on the one hand, and the radical or progressive camp on the other, with some people in between who shift between camps from topic to topic. The natures of these apparently distinct groupings will now be further explored.

\section{Further Insights}

Specifically, in drawing out further insights from the data, several pairs of variables were plotted, the most interesting of which are presented in Figure 1a-f and then discussed below. 


\section{Figure 1: Inter-variable relationships}

\section{INSERT FIGURE 1 HERE}

Figure 1a maps two variables, Car Ownership Trends versus Likelihood of AV adoption. From this, car ownership is expected to decline most markedly amongst those who definitely or probably expect AVs to be adopted in the fairly near future, perhaps suggesting that most interviewees were positive about the expected societal impacts of AVs. The international observers seemed more cynical about this effect than the other interviewees (one out of five interviewees unconvinced compared to only three out of twenty interviewees from the other three groups).

Figure $1 \mathrm{~b}$ shows how the Vehicle Size may change depending on the Likelihood of AV adoption. This serves to explore the idea that increased automation will lead to smaller vehicles due to the economics of public transport operation being transformed by drivers no longer being required. Here the figures do suggest that those who expect $A V s$ to be adopted were far more likely to mention the shift to smaller vehicles than those who did not expect AVs to be adopted. Thus, 15 interviewees who saw AVs definitely or probably being adopted by 2045 explicitly mentioned smaller public transport vehicles emerging over the period, compared to only one interviewee who both did not expect AVs to be adopted and mentioned smaller vehicles. However, even in the 'expect AV adoption' categories more interviewees did not explicitly mention smaller vehicles (21) than did (15).

Figure 1c, illustrating the Degree of Route Flexibility versus Mode of Steering Control shows that 30 out of the 50 interviewees expect public transport to shift to more flexible routeing (and timetabling) pattern in the future. Interestingly, whilst one might have anticipated that AVs would lend themselves more to providing more point-to-point/personalised service patterns, the ratios are actually remarkably similar for those who expect vehicles to be manually steered (eleven out of 27 interviewees), compared with those who expect public transport vehicles to be steered without the need for a driver (nine out of 23).

Figure 1d presents a plot showing how the Importance of Climate Change relates to the Expected Public Transport User Market. This suggests that those who explicitly mentioned the environment and/or climate change as being important were more convinced that the use of public transport would become more widespread in the future (12 out of 20 interviewees), whilst those who did not express this view were likely to see only socially disadvantaged groups as using public transport (ten out of 20). However, the pattern was reversed for government officials, where five out of nine 'climate optimists' did not explicitly mention Climate Change as being an important influence on public transport, but three out of five 'climate pessimists' did so.

Figure 1e compares the Importance of Climate Change versus Likelihood of AV adoption., Here, no apparent differences were revealed when comparing the number of interviewees who explicitly mentioned Climate Change exactly balancing those who did not (21 interviewees each). The figures also closely matched for each Level of AV adoption category and for each stakeholder group. This finding seems to conflict slightly with both the Vehicle Ownership versus Likelihood of AV adoption and the Importance of Climate Change versus Expected Public Transport User Market plots, which seemed to suggest that there would be noticeable differences in this case. 
Figure 1f, explores how the Importance of Technology is related to the Operational Environment This revealed that of the 32 interviewees who explicitly mentioned technology as being a major influence on the development of public transport in the future, just over half (18) also mentioned that the private sector would play a major role in pushing that development, whilst 14 made no comment on which stakeholders would drive the process. This finding indicates that the interviewees see private sector operators as being far more strongly associated with (potentially radical) technological developments and by extension on the delivery of public transport than public sector and/or community operators would be. It is especially interesting in a world where private companies such as Uber, Lyft and Flixbus are already using technology to radically shake up the passenger transport market, whilst Original Equipment Manufacturers are investing heavily in the development of Autonomous Vehicles for instance.

\section{Resulting Scenarios}

As explained in the methodology, the interview findings were used to inform the development of a series of scenarios, which were then validated in four workshop exercises. Each scenario comprised an observation on city life from an urban resident in 2045; how we could get to this future, with transitions in transport over the next thirty years; a summary of how people travel in the future; and a visual overview of speculative transport data in 2045. Each of the scenarios assumed that urban areas would continue to grow.

The scenarios that resulted from the process are summarised in Figure 2, and the full details are reported in NZMOT (2018). In brief, four possible futures were derived by combining the uncertainties faced around transport automation (partial or full automation by 2045) and urban density (high/low).

\section{Figure 2: PT2045 scenarios summarised}

\section{INSERT FIGURE 2 HERE}

\section{Implications and conclusions for practice and policy}

From these results, and particularly from the scenarios, four key implications for policy and practice emerge, namely:

The transport system is about to transition to a system of 'shared mobility'. Three of the four scenarios envisage futures where private car ownership has dramatically fallen because alternatives have developed that people find more attractive. So, in 'Shared Shuttles', increasing urban density makes it easier for many people to access work, education, recreation, and friends or family via short trips. It also makes shared services more financially viable, with more people living within service catchment areas. People often travel by walking, cycling, and sharing rides in minibuses or shuttles that are readily available on demand. In 'Connected Corridors', densely populated urban areas are served by fully automated transport technologies with all vehicles driving autonomously within urban boundaries. Self-driving trains or rapid buses operate on high capacity shared transport corridors, which people can transfer to/from via fleets of self-driving taxis. In 'Personalised Pods', most people still favour having access to personal cars due to low urban density. They regularly travel across town and make long commutes in fully automated 'pods'. These vehicles are owned by corporate fleet providers and are bookable in advance or on demand. Vehicles in these fleets form part of an intelligent network that aims to minimise congestion and journey times. The only scenario where 
private cars still dominate is 'Mobility Market'. This world is characterised by low urban density and only partially automated vehicles - the scenario that is closest to today. These scenarios imagine very different urban transport systems, driven largely by the advent of new (particularly AV and 'big data') technologies that are rapidly developing currently, and by (slower) shifts towards higher urban densities over time.

Public transport will need to evolve to stay relevant. Services will need to become more flexible, more frequent, and more responsive to travellers' needs. For instance, demand-responsive shuttles could replace many low-frequency scheduled bus services and routes, and MaaS platforms could make it easier for operators to offer services and for people to use them. There is also a need for dedicated rapid transit corridors to enable rapid transit services to avoid being delayed by single-occupancy vehicles. This makes journey times quicker, more reliable, and enables more passengers to travel on the route. In the future, some high capacity shared transport corridors could potentially be used by a greater variety of vehicles (e.g. convoys of small self-driving high occupancy vehicles). Vehicle-sharing and ride-sharing services will also likely complement public transport to develop an inter-connected shared mobility system. However, it should be noted that people are only going to share vehicles and rides if these alternatives are more attractive (e.g. more convenient and price competitive), and if people feel safe and comfortable doing so. Cultural norms, vehicle designs, and legal rules around data sharing will also need to be changed if such a shift is to occur.

Public transport will remain important in any scenario. Public transport will continue to be seen as being a public good for several key reasons, and therefore legitimately worthy of government support. First, ensuring inclusive access for those who do not drive or cannot afford their own private motorised vehicle could be achieved if vehicle sharing schemes enabled by 'Mobility-as-a-Service' platforms become more widespread, particularly if AV technology makes providing these services far more affordable and attractive to consumers. Second, many of the environmental harms caused by transport could be limited after a shift away from ICE-propelled vehicles to electric and/or hydrogen vehicles coupled with a more attractive public transport offer (as described previously). Third, congestion could be managed if people transferred to public transport and new technologies led to more efficient use of infrastructure. Fourth, urban form and liveability could be improved if vehicles were more effectively utilised and did not require, for example, as much parking space as at present. By contrast, there is a strong risk that several undesirable consequences could emerge if public transport solutions were disregarded. For instance, if personal motorised travel becomes easier then people may walk and cycle less, with negative health impacts. And if personal motorised travel becomes cheaper (with no parking costs) and more enjoyable (with occupants' attention liberated from driving), many people are likely to opt for cheaper and/or larger houses on urban fringes and accept increasingly longer commutes thus increasing urban sprawl and amplifying traffic volumes and congestion.

The role of Government will be vital in the future and in overseeing the transition to the shared mobility era. In realising the societal benefits of local passenger transport, three areas in particular are important. Firstly, transport needs to be properly priced to better reflect the societal costs it imposes. Modern technology means this could be done through some form of charging mechanism based on a range of factors such as time of travel, location, vehicle occupancy, emissions generated, and level of demand for the infrastructure, as well as on individual traveller attributes such as the ability of individuals to pay and even the economic desirability of the trip from a societal perspective! 
Clearly, any form of subsidy regime would also need to be incorporated as part of this. Secondly, government needs to consider a desirable direction for the development and uptake of new passenger transport and related technologies (such as AVs), perhaps by incentivising these technologies in ways that support safety, accessibility, urban liveability, and wellbeing while reducing greenhouse gas emissions either financially or via regulatory mechanisms. Thirdly, regulatory models for passenger transport will need to adapt to take advantage of new technologies and business models. This could involve a shift away from traditional structures that are formed in modal silos, towards cross-modal rule systems for service delivery levels, vehicle standards etc.

\section{Originality, Rigour and Significance}

Overall, this work is original because it is the first study to take such a broad view of the long-term future passenger transport system whilst using such a qualitatively rich and globally diverse set of interview and workshop data. Specifically, the study draws on 50 in-depth interviews with practitioners from New Zealand and from around the world, the results of which were then validated at four workshops which were attended by 28 practitioners in total. Finally, it is significant in that it is being used to inform transport and broader policy efforts at both local and national government levels across New Zealand.

\section{Research data for this article}

Due to the fact that the questions asked in this study were intended primarily for a Government study, survey interviewees were assured raw data would remain confidential and would not be shared.

\section{References}

Angelidou M, Genitsaris E, El Aissati H and Naniopoulos A (2017) The effect of major market and societal trends on public transport in European cities, Transportation Research Procedia, 24, 105112.

Agarwal O P, Kumar A and Zimmerman S (2019) Public Transit: From Compulsion to Choice (in ed. Agarwal O P, Kumar A and Zimmerman S), Emerging Paradigms in Urban Mobility, Elsevier, Amsterdam, Chapter 4, 77-99.

Arbib J and Seba T (2017) Rethinking Transportation 2020-2030, The Disruption of Transportation and the Collapse of the Internal-Combustion Vehicle and Oil Industries, A RethinkX Sector Disruption Report, May. Visit https://www.rethinkx.com/transportation. Last accessed 28 May 2019.

Bansal P and Kockelman K M (2017) Forecasting Americans' long-term adoption of connected and autonomous vehicle technologies, Transportation Research Part A: Policy and Practice, 95, 49-63.

Bood R, and Postma T J B M (1997) Strategic learning with scenarios. European Management Journal, 15, 633-647.

Boyatzis R E (1998) Transforming qualitative information: Thematic analysis and code development, Sage Publications, London.

Braun V and Clarke V (2006) Using thematic analysis in psychology, Qualitative Research in Psychology, 3, (2), 77-101. 
Canitez F (2019) Pathways to sustainable urban mobility in developing megacities: A socio-technical transition perspective, Technological Forecasting and Social Change, 141, 319-329.

Cohen A P and Shaheen S A (2013) Planning for shared mobility, PAS Report 583, American Planning Association, Chicago.

Committee for Review of Innovative Urban Mobility Services (2016) Between Public and Private Mobility: Examining the Rise of Technology-Enabled Transportation Services, Special Report 319, Transportation Research Board, The National Academies Press, Washington, DC. Visit https://doi.org/10.17226/21875. Last accessed 17 February 2020.

Corazza M V, Guida U, Musso A and Tozzi M (2016) A European vision for more environmentally friendly buses, Transportation Research Part D: Transport and Environment, 45, 48-63.

Cramer J and Krueger B (2016) Disruptive change in the taxi business: the case of uber, American Economic Review, 106(4), 177-182.

Cruikshanks S and Waterson B (2012) Will Privacy Concerns Associated with Future Transport Systems Restrict the Public's Freedom of Movement? Procedia - Social and Behavioural Sciences 48, 941-950.

Dargay J, Gately D and Sommer M (2007) Vehicle Ownership and Income Growth, Worldwide: 19602030, The Energy Journal, 28(4), 143-170

Delbosc A and Currie G (2013) Causes of Youth Licensing Decline: A Synthesis of Evidence. Transport Reviews 33(3), 271-290.

Docherty I, Marsden G, and Anable J (2018) The governance of smart mobility, Transportation Research Part A: Policy and Practice, 115, 114-125.

Durand A, Harms L, Hoogendoorn-Lanser S and Zijlstra T (2018) Mobility-as-a-Service and changes in travel preferences and travel behaviour: a literature review, Report KiM 18 A17, KiM Netherlands Institute for Transport Policy Analysis, Ministry of Infrastructure and Water Management, The Hague, September.

Edelenbosch O Y, Kermeli K, Crijns-Graus W, Worrell E, Bibas R, Fais B, Fujimori S, Kyle P, Sano F, and van Vuuren DP (2017) Comparing projections of industrial energy demand and greenhouse gas emissions in long-term energy models, Energy, 122, 701-710.

Enoch M P (2015) How a Rapid Modal Convergence into a Universal Automated Taxi Service could be the Future for Local Passenger Transport, Technology Analysis and Strategy Management, 27(8), 910-924.

Enoch M P and Potter S (2016) Paratransit: the need for a regulatory revolution in the light of institutional inertia, (in ed. Mulley, C and Nelson, J D) Paratransit: Shaping the Flexible Transport Future. Emerald, Shipley, West Yorkshire, 15-34.

Fagnant D J and Kockelman K (2014) Preparing a Nation for Autonomous Vehicles: Opportunities, Barriers, and Policy Recommendations for Capitalising on Self Driven Vehicles. Poster presentation at 
the 93rd annual meeting of the Transportation Research Board, Paper 14-1281, Session 697, Current Research Findings on Vehicle-Highway Automation Systems, Vehicle-Highway Automation Committee, Transportation Research Board, National Academy of Science, Washington, DC, January $12-16$.

Federal Highway Administration (2016) Understanding travel behaviour Research Scan, FHWA Grant DTFH61-13-D-00013, US Department of Transportation, Washington DC.

Fernández-Isabel A, Fuentes-Fernández R and Martín de Diego (2020) Modeling multi-agent systems to simulate sensor-based Smart Roads, Simulation Modelling Practice and Theory, 99, Article 101994.

Gecchelin T and Webb J (2019) Modular dynamic ride-sharing transport systems, Economic Analysis and Policy, 61, 111-117.

Gläser J and Laudel G (2004) Experteninterviews und qualitative inhaltsanalyse, VS Verlag für Sozialwissenschafen, Wiesbaden.

Government Office for Science (2019) The future of mobility, Foresight, Government Office for Science, London, 31 January. Visit https://www.gov.uk/government/publications/future-of-mobility. Last accessed 25 February 2019.

Hamari J, Mimmi S, and Antti U (2016) The sharing economy: why people participate in collaborative consumption, Journal of the Association of Information, Science and Technology, 67(9), 2047-2059.

Hannon E, McKerracher C, Orlandi I and Ramkumar S (2016) An integrated perspective on the future of mobility, McKinsey and Company, Frankfurt, October.

Hua T, Ahluwalia R, Eudy L, Singer G, Jermer B, Asselin-Miller N, Wessel S, Patterson T and Marcinkoski J (2014) Status of hydrogen fuel cell electric buses worldwide, Journal of Power Sources, 269, 975-993.

Ingvardson J B and Nielsen OA (2018) How urban density, network topology and socio-economy influence public transport ridership: Empirical evidence from 48 European metropolitan areas, Journal of Transport Geography, 72, forthcoming.

International Organization of Motor Vehicle Manufacturers (2015) Motorisation rate 2015 worldwide, OICA, Paris. Visit http://www.oica.net/category/vehicles-in-use/. Last accessed 28 May 2019.

Jittrapirom P, Marchau V, van der Heijden R and Meurs H (2018) Future implementation of mobility as a service (MaaS): Results of an international Delphi study, Travel Behaviour and Society, forthcoming.

Julsrud T E and Priya Uteng T (2015) Technopolis, shared resources or controlled mobility? A netbased Delphi-study to explore visions of future urban daily mobility in Norway, European Journal of Futures Research, 3(10), 1-13. 
KPMG (2019) Mobility 2030, 19 February. Visit

https://home.kpmg/uk/en/home/insights/2017/04/mobility-2030.html. Last accessed 25 February 2019.

Kvale S (1996) Interviews: An introduction to qualitative research interviewing, Sage, London.

Linz M (2012) Scenarios for the aviation industry: A Delphi-based analysis for 2025, Journal of Air Transport Management, 22, 28-35.

Miles M B and Huberman A M (1994) Qualitative data analysis, 2nd Edition, Sage Publications, Thousand Oaks.

Milne D and Watling D (2018) Big data and understanding change in the context of planning transport systems, Journal of Transport Geography, forthcoming.

Nelson J D and Mulley C (2013) The impact of the application of new technology on public transport service provision and the passenger experience: A focus on implementation in Australia, Research in Transportation Economics, 39(1), 300-308.

Newman P and Kenworthy J (2011) Peak car use: understanding the demise of automobile dependence, World Transport Policy and Practice, 17(2), 31-42.

New Zealand Ministry of Transport (2018) Public Transport 2045, Working paper on urban transport in the shared mobility era, NZMOT, Wellington, New Zealand, 15 November. Visit https://apo.org.au/node/204596. Last accessed 12 April 2019.

Olivková I (2017) Comparison and Evaluation of Fare Collection Technologies in the Public Transport, Procedia Engineering, 178, 515-525.

Potter S, Valdez A and Cook M (2019) Autonomous vehicles and the urban mobility ecosystem, in Nuttall, W, Gibson D, Trzmielak D and Ibarra-Yunez, A eds. Energy and Mobility in Smart Cities. ICE Publishing, 83-97.

Sakaria N and Stehfast N (2013) Millennials and Mobility: Understanding the Millennial Mindset and New Opportunities for Transit Providers. Washington, DC: The National Academies Press. Visit https://doi.org/10.17226/22500. Last accessed 17 February 2020.

Scheiner J (2014) Gendered key events in the life course: effects on changes in travel mode choice over time, Journal of Transport Geography, 37, 47-60.

Shaheen S A and Cohen A P (2013) Carsharing and Personal Vehicle Services: Worldwide Market Developments and Emerging Trends. International Journal of Sustainable Transportation, 7(1), 5-34.

Shaheen S A, Cohen A P, Zohdy I (2016) Shared Mobility: Current Practices and Guiding Principles, Federal Highway Administration, U.S. Department of Transportation, Washington DC.

Shaheen S A, Cohen A P, Yelchuru B, and Sarkhili S (2017) Mobility on Demand Operational Concept Report, Intelligent Transportation Systems Joint Program Office, U.S. Department of Transportation, Washington DC, September. 
Shaheen S A and Cohen A P (2018) Is It Time for a Public Transit Renaissance? Navigating Travel Behavior, Technology, and Business Model Shifts in a Brave New World, Journal of Public Transportation, 21 (1), 67-81.

Shaheen S A, Totte H and Stocker A (2018) Future of Mobility White Paper, UC Berkeley, California Digital Library, Berkeley CA, January. Visit https://escholarship.org/uc/item/68g2h1qv. Last accessed 17 February 2020.

Shergold I, Lyons G, and Hubers C (2015) Future mobility in an ageing society - Where are we heading? Journal of Transport and Health, 2(1), 86-94.

Smith G, Sochor J, and Karlsson I C M (2018) Mobility as a Service: Development scenarios and implications for public transport, Research in Transportation Economics, 69, 592-599.

Sochor J, Arby H, Karlsson M and Sarasini S (2017) A topological approach to Mobility as a Service: A proposed tool for understanding requirements and effects, and for aiding the integration of societal goals, Paper presented at The 1st International Conference on Mobility as a Service (ICoMaaS), Tampere, 28-29 November.

Sperling, D. and Gordon, D. 2009. Two billion cars: Driving toward sustainability, Oxford University Press, Oxford.

Spickermann A, Grienitz V, and von der Gracht H A (2014) Heading towards a multimodal city of the future? Multi-stakeholder scenarios for urban mobility, Technological Forecasting and Social Change, 89, 201-221.

Stokes G (2013) The prospects for future levels of car access and use. Transport Reviews, 33(3), 360375.

Stephenson J, Spector S, Hopkins D and McCarthy A (2018) Deep interventions for a sustainable transport future, Transportation Research Part D: Transport and Environment, 61B, 356-372.

Van der Heijden K (2005) Scenarios: The Art of Strategic Conversation, John Wiley and Son, Chichester.

Villagra J J, Milanés V, Pérez J and Godoy J (2012) Smooth path and speed planning for an automated public transport vehicle, Robotics and Autonomous Systems, 60(2) 252-265.

Vuchic V R (2007) Urban Transit: Systems and Technology. Wiley, Englewood, NJ.

Wang B (2019) Around 100m vehicles will be sold in 2019 and bring vehicles in use to about 1.5 billion. Next Big Future, 6 February. Visit https://www.nextbigfuture.com/2019/02/around-100million-vehicles-will-be-sold-in-2019-and-bring-vehicles-in-use-to-about-1-5-billion.html. Last accessed 17 February 2020.

Webb J (2019) The future of transport: Literature review and overview, Economic Analysis and Policy, 61, 1-6.

Zmud J, Ecola L, Phleps P and Feige I (2013) The Future of Mobility: Scenarios for the United States in 2030. Institute for Mobility Research. Rand Corporation, Santa Monica, CA. 
Figure 1: Inter-variable relationships

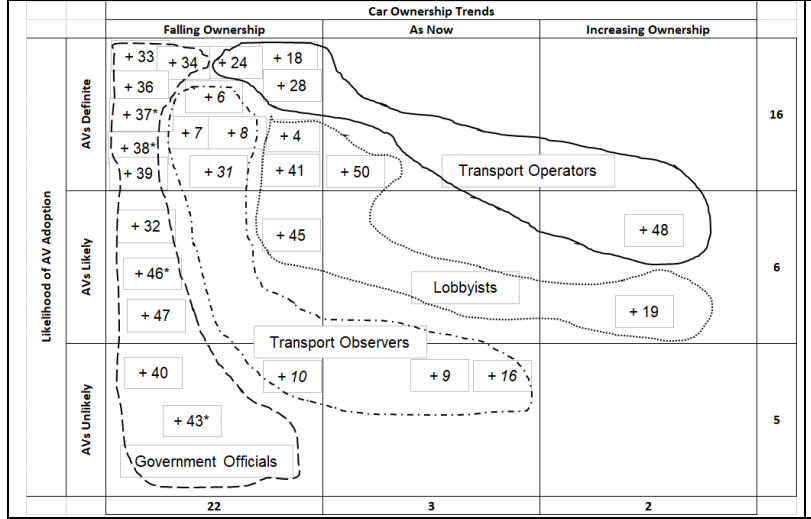

a) Car Ownership Trends versus Likelihood of AVs

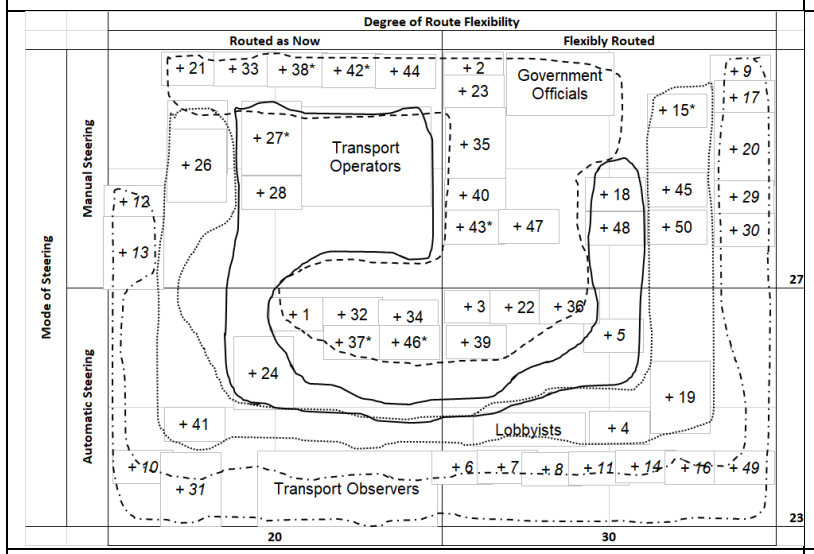

c) Degree of Route Flexibility versus Mode of Steering Control

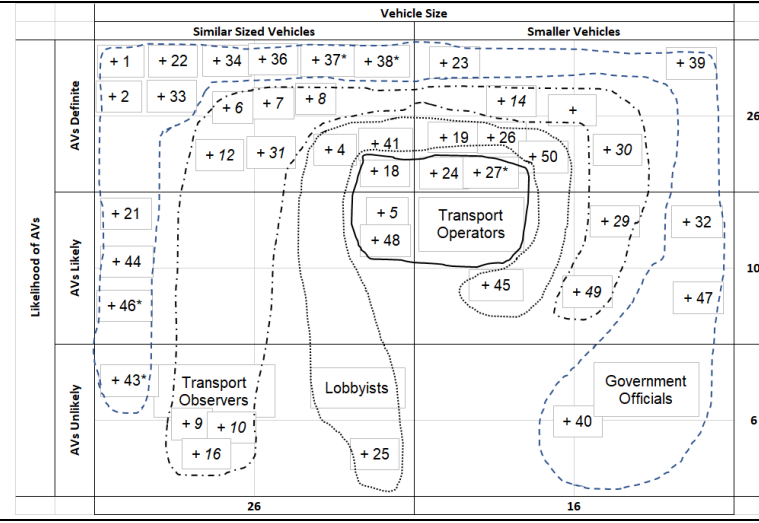

b) Vehicle Size versus Likelihood of AVs

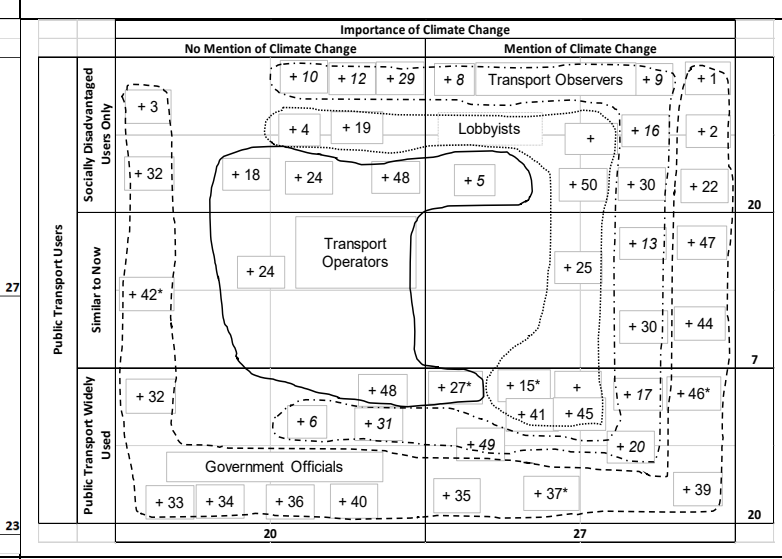

d) Importance of Climate Change versus Expected Public Transport User Market

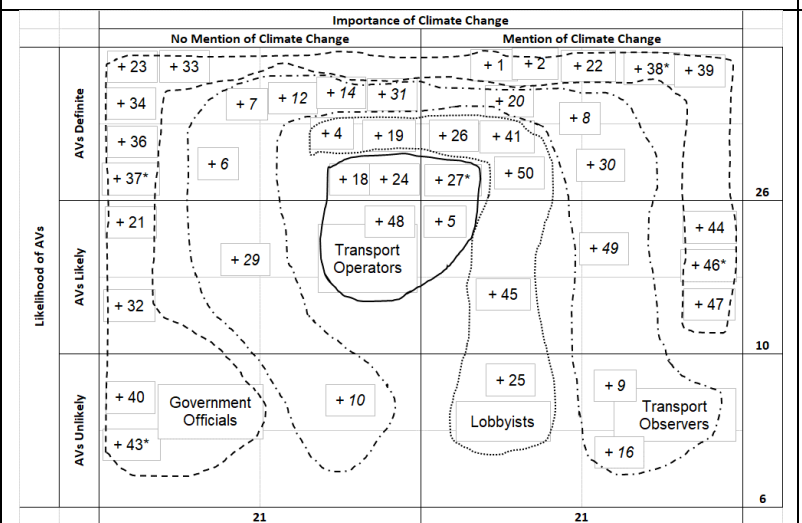

e) Importance of Climate Change versus Likelihood of AVs

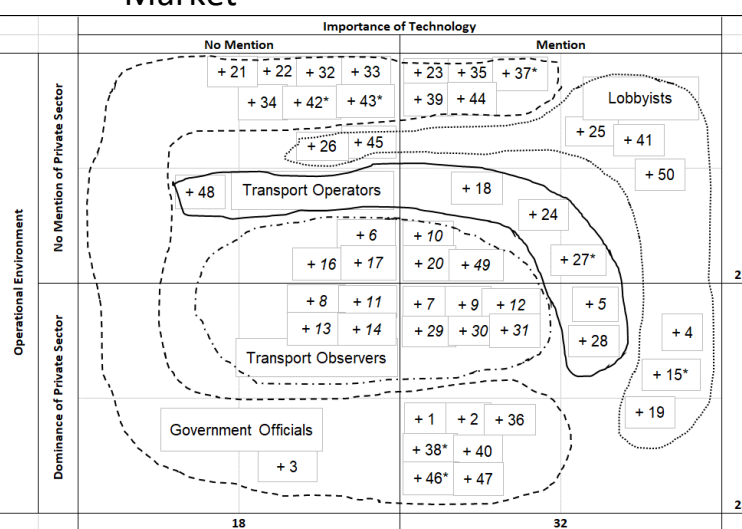

f) Importance of Technology versus Operational Environment 


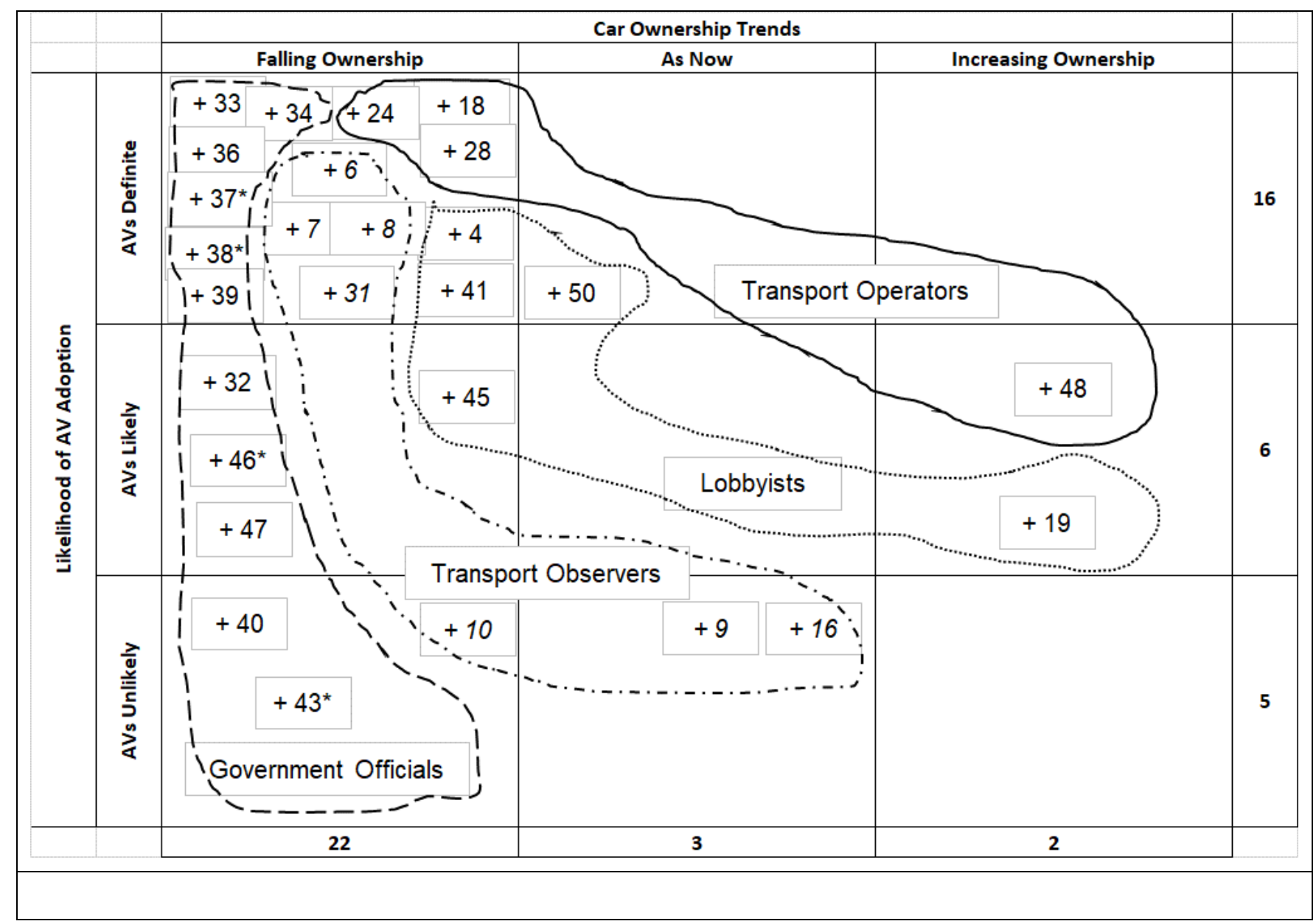

1a Car Ownership Trends versus Likelihood of AVs 


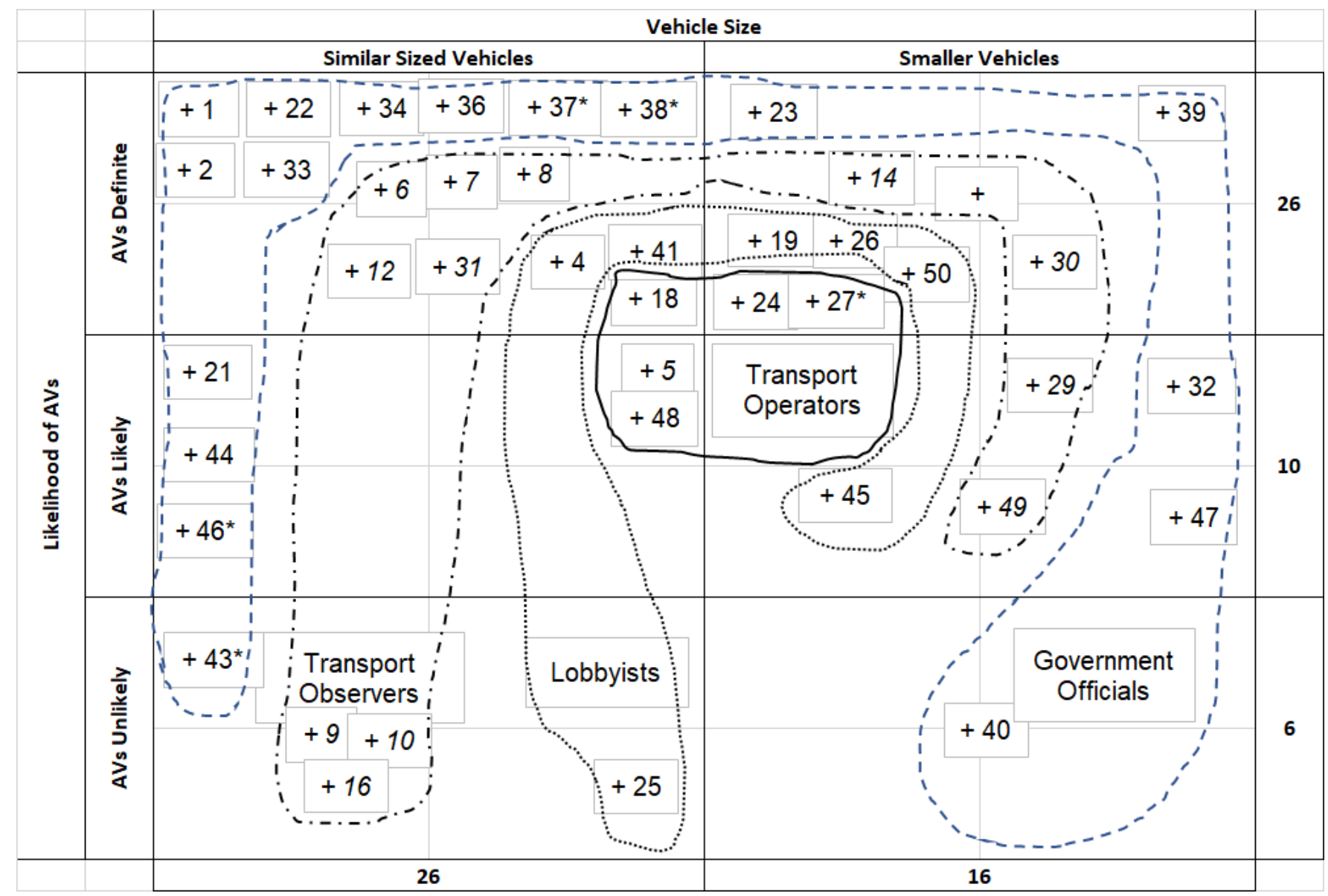

1b Vehicle Size versus Likelihood of AVs 


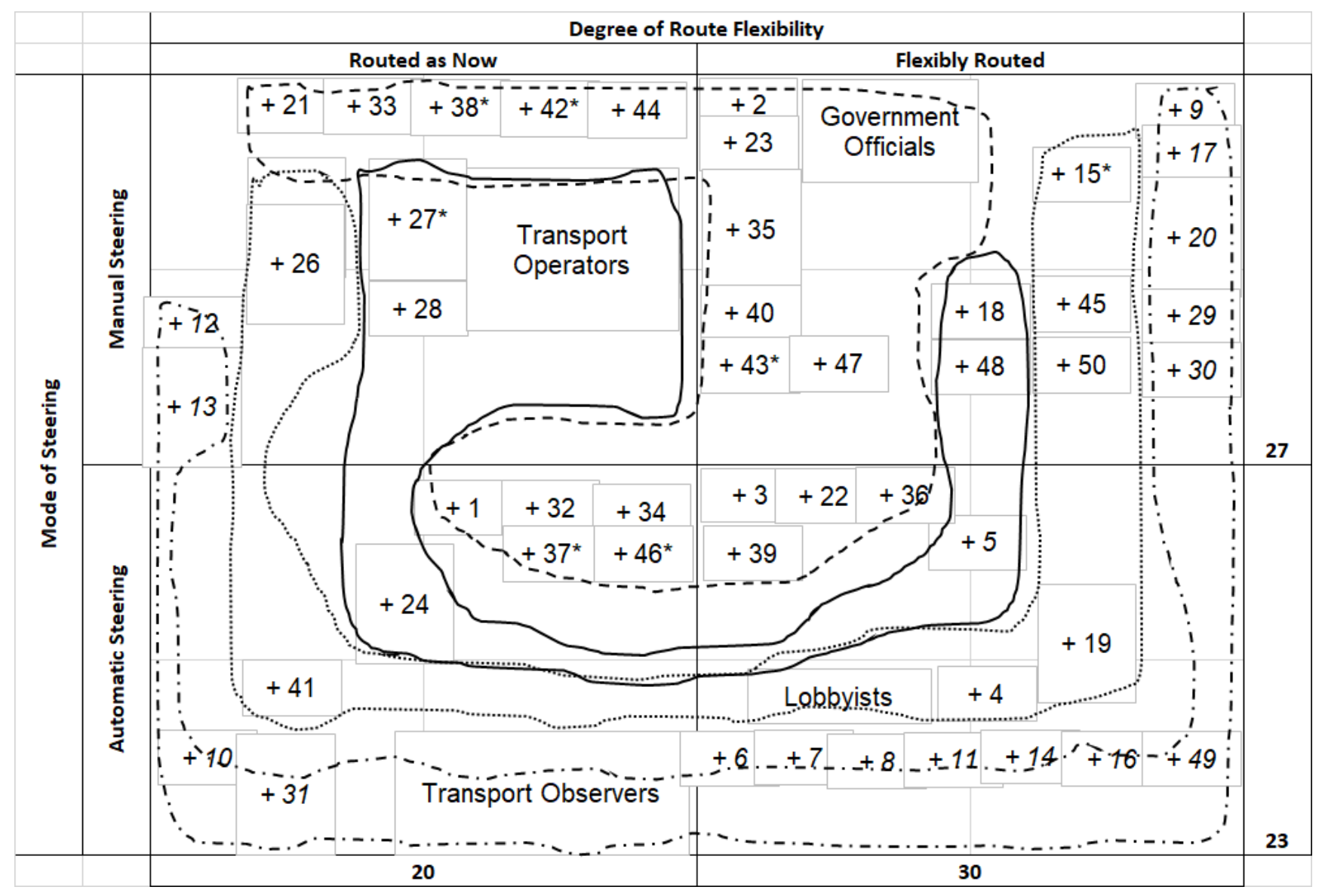

1c Degree of Route Flexibility versus Mode of Steering Control 


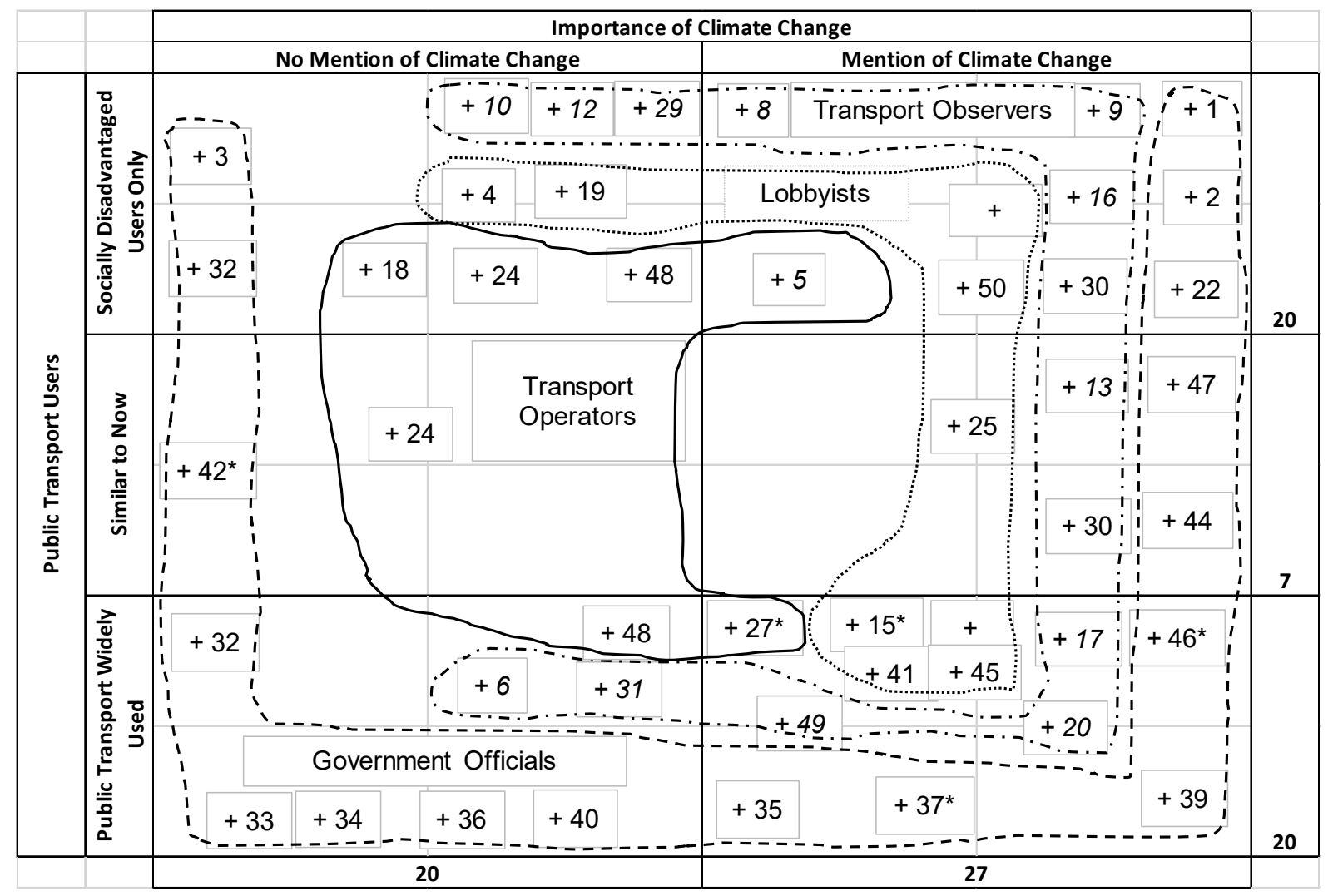

1d Importance of Climate Change versus Expected Public Transport User Market 


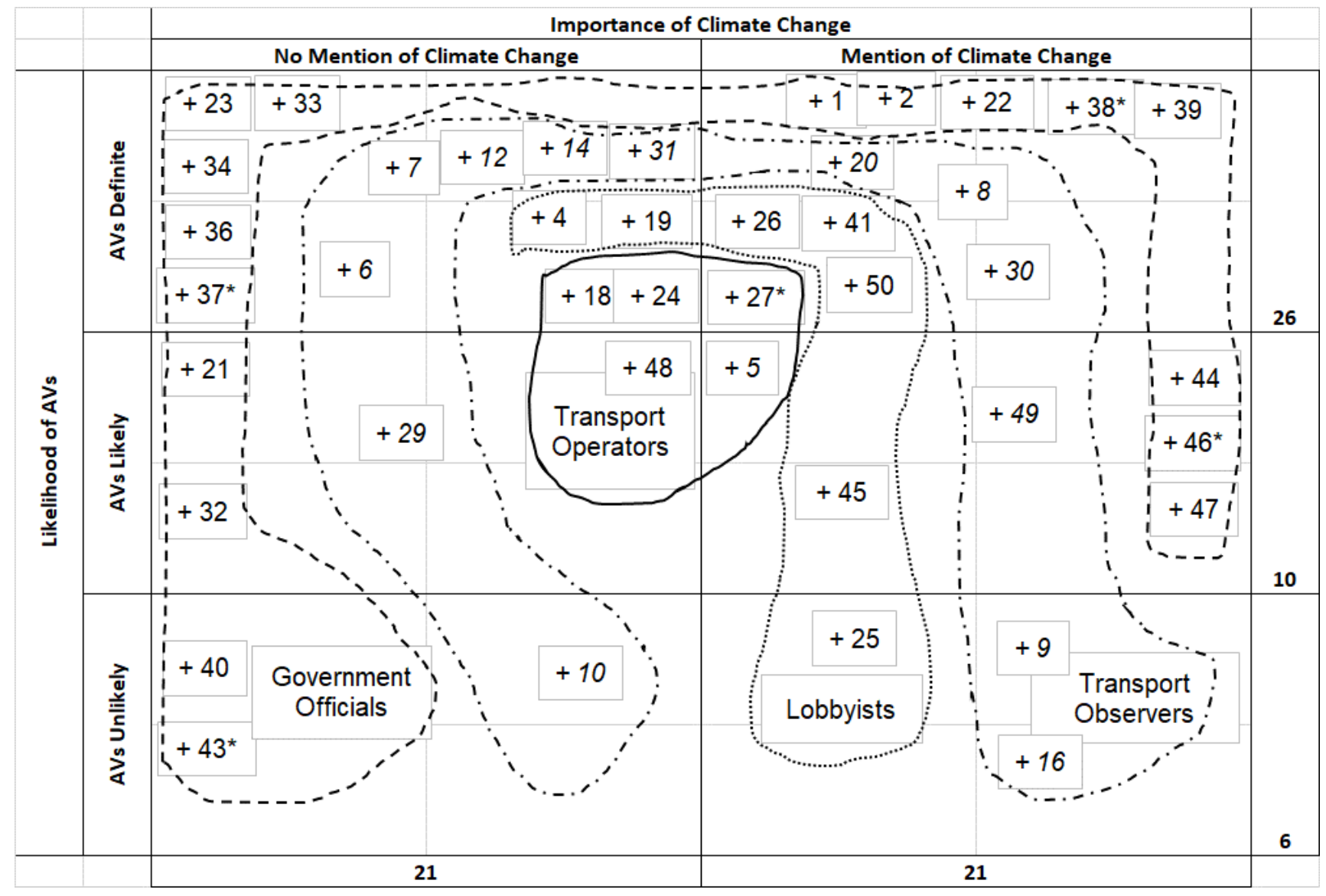

1e Importance of Climate Change versus Likelihood of AVs 


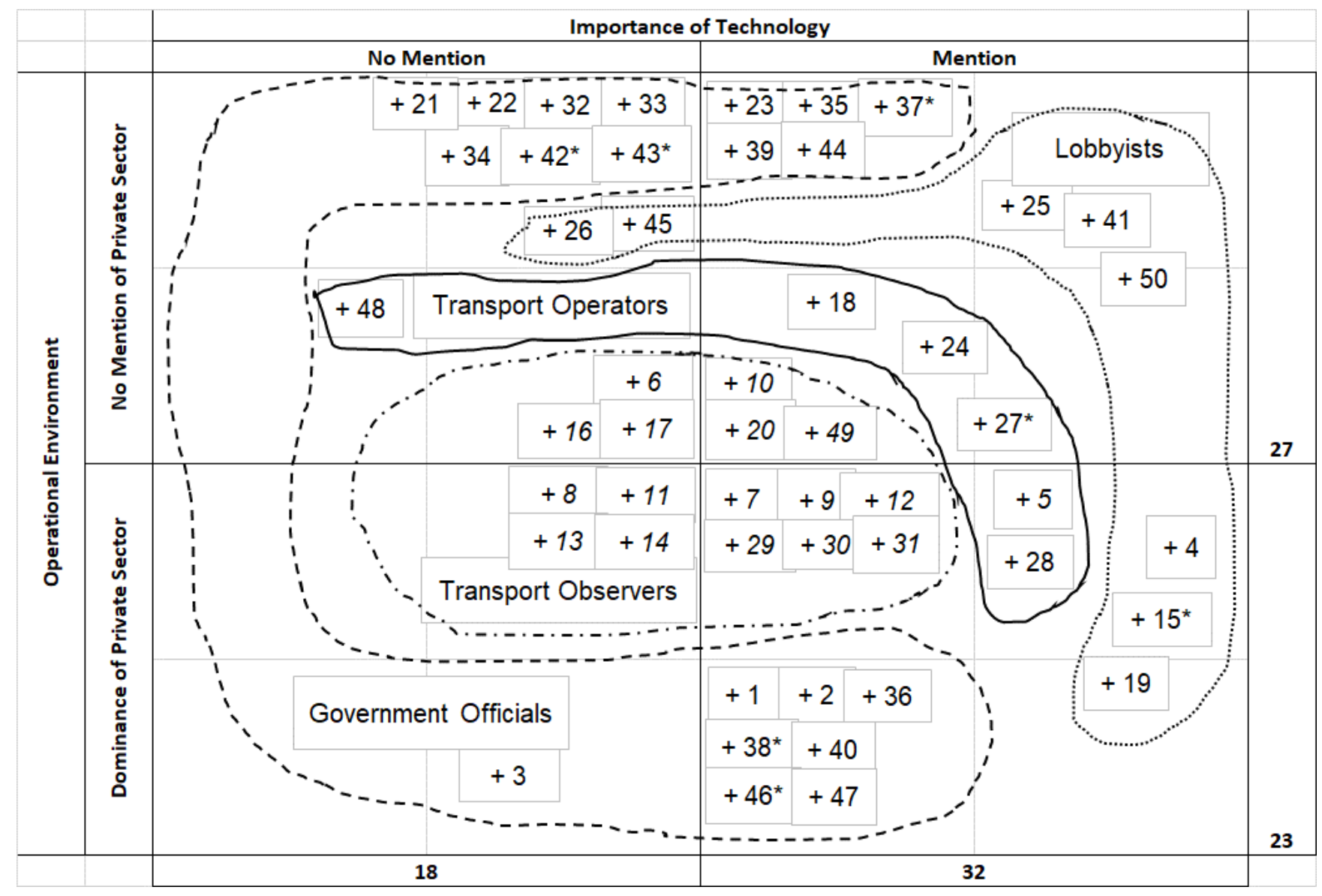

If Importance of Technology versus Operational Environment 
Figure 2: PT2045 scenarios summarised

SHARED SHUTTLES

Choices abound for those willing to share. Ride-sharing and mini bus services shuttle many people around town, when they aren't walking, biking, and scooting around compact urban centres.

\section{HIGH DENSITY}

\section{$\hat{4}$}

Intelligent networks of automated buses, rail services, and cars rapidly move people on major transport corridors.

Travellers are automatically guided along routes and services by their all-knowing personalised travel apps.

\section{PERSONALISED PODS}

Fleets of autonomous 'pods' have replaced all bus services and most privately-owned cars. Pods offer affordable on demand travel from point to point, with people using pods privately or sharing rides for cheaper trips. customised 'mobility packages' with prepaid allowances to use on different travel modes and services, including bus and rail options.

\section{LOW DENSITY}


Table 3 Interviewee details

\begin{tabular}{|c|c|c|c|}
\hline Role & Sector & NZ (35) & International (15) \\
\hline \multirow{3}{*}{$\begin{array}{l}\text { National } \\
\text { Government } \\
\text { official (16) }\end{array}$} & Transport (6) & $\begin{array}{l}{[1],[2],[3],[21],} \\
{[22],[23]}\end{array}$ & \\
\hline & $\begin{array}{l}\text { Public Transport } \\
\text { (6) }\end{array}$ & $\begin{array}{l}{[35],\left[42^{*}\right],\left[43^{*}\right],} \\
{[44],\left[46^{*}\right],[47]}\end{array}$ & \\
\hline & Planning etc (4) & $\begin{array}{l}{\left[37^{*}\right],\left[38^{*}\right],[39],} \\
{[40],}\end{array}$ & \\
\hline \multirow{2}{*}{$\begin{array}{l}\text { Local } \\
\text { Government } \\
\text { official (4) }\end{array}$} & Transport (2) & [32], [36], & \\
\hline & $\begin{array}{l}\text { Public Transport } \\
\text { (2) }\end{array}$ & [33], [34], & \\
\hline \multirow{3}{*}{$\begin{array}{l}\text { Operator (5) } \\
\text { Equipment } \\
\text { provider (1) }\end{array}$} & $\begin{array}{l}\text { Public Transport } \\
\text { (2) }\end{array}$ & [18], & [5], \\
\hline & New modes (3) & {$\left[27^{*}\right],[28],[48]$} & \\
\hline & Planning etc (1) & [24], & \\
\hline \multirow[b]{5}{*}{ Lobbyist (8) } & Transport (1) & [19], & \\
\hline & $\begin{array}{l}\text { Public Transport } \\
\text { (3) }\end{array}$ & {$\left[15^{*}\right],[41],[50]$} & \\
\hline & Planning etc (1) & [45], & \\
\hline & Green (2) & [4], [25], & \\
\hline & New modes (1) & [26], & \\
\hline Observer (16) & Transport (16) & [17], [30] & $\begin{array}{l}{[6],[7],[8],[9],} \\
{[10],[11],[12],} \\
{[13],[14],[16],} \\
{[20],[29],[31],} \\
{[49]}\end{array}$ \\
\hline
\end{tabular}

NOTE: * denotes a female interviewee. 
Table 4: Vehicle ownership expectations by interviewee type

\begin{tabular}{|c|c|c|c|c|c|}
\hline Role & Sector & Falling ownership & As now & $\begin{array}{l}\text { Increasing } \\
\text { ownership }\end{array}$ & Unsure \\
\hline \multirow{3}{*}{$\begin{array}{l}\text { National } \\
\text { Government } \\
\text { official }\end{array}$} & Transport & [3], & & & {$[21],[23]$} \\
\hline & Public Transport & $\begin{array}{l}{[35],\left[43^{*}\right],\left[46^{*}\right],[4} \\
7]\end{array}$ & & & [44] \\
\hline & Planning etc & $\begin{array}{l}{\left[37^{*}\right],\left[38^{*}\right],[39]} \\
{[40],}\end{array}$ & & & \\
\hline \multirow{2}{*}{$\begin{array}{l}\text { Local } \\
\text { Government } \\
\text { official }\end{array}$} & Transport & {$[32],[36]$} & & & \\
\hline & Public Transport & [33], [34], & & & \\
\hline \multirow[b]{2}{*}{ Operator } & Public Transport & [18], & & & \\
\hline & New modes & {$\left[27^{*}\right],[28]$} & & [48] & \\
\hline $\begin{array}{l}\text { Equipment } \\
\text { provider }\end{array}$ & Planning etc & [24] & & & \\
\hline \multirow[b]{5}{*}{ Lobbyist } & Transport & & & [19] & \\
\hline & Public Transport & {$\left[15^{*}\right],[41]$} & [50] & & \\
\hline & Planning etc & {$[45]$} & & & \\
\hline & Green & [4], & & & [25] \\
\hline & New modes & & & & \\
\hline \multirow[t]{2}{*}{ Observer } & Transport & $\begin{array}{l}{[6],[7],[8],[10],[2} \\
0],[31],[49]\end{array}$ & {$[9],[13],[16],[17]$,} & & {$[12],[14],[29]$} \\
\hline & Responses & 28 & 5 & 2 & 7 \\
\hline
\end{tabular}

NOTE: * denotes a female interviewee, and italic script denotes an international interviewee. 
Table 5: Public transport futures by interviewee type

\begin{tabular}{|c|c|c|c|c|c|c|c|c|}
\hline Role & Sector & $\begin{array}{l}\text { Mass Transit } \\
\text { Used on Corridors }\end{array}$ & $\begin{array}{l}\text { Not Much } \\
\text { Change in Types } \\
\text { of Public } \\
\text { Transport }\end{array}$ & $\begin{array}{l}\text { More Demand } \\
\text { Responsive } \\
\text { Shuttles }\end{array}$ & $\begin{array}{l}\text { More Shared } \\
\text { Transport } \\
\text { Services }\end{array}$ & $\begin{array}{l}\text { More Blended } \\
\text { Shared/ Mass } \\
\text { Transport }\end{array}$ & $\begin{array}{l}\text { Broader Range of } \\
\text { Public Transport } \\
\text { Modes }\end{array}$ & $\begin{array}{l}\text { Demi } \\
\text { Servic }\end{array}$ \\
\hline \multirow{3}{*}{$\begin{array}{l}\text { National } \\
\text { Government } \\
\text { official }\end{array}$} & Transport & $\begin{array}{l}{[1],[2],[3],[22],} \\
{[23]}\end{array}$ & [21] & {$[2],[3],[21],[23]$} & & & & \\
\hline & Public Transport & $\begin{array}{l}{[35],\left[42^{*}\right],\left[43^{*}\right],} \\
{[44],\left[46^{*}\right],[47]}\end{array}$ & & $\begin{array}{l}{[35],\left[43^{*}\right],[44]} \\
{\left[46^{*}\right],[47]}\end{array}$ & {$\left[46^{*}\right]$} & [35] & {$\left[43^{*}\right],[44],\left[46^{*}\right]$} & \\
\hline & Planning etc & {$\left[38^{*}\right],[39],[40]$,} & & {$\left[38^{*}\right],[39],[40]$,} & {$\left[37^{*}\right],\left[38^{*}\right],[40]$} & $\begin{array}{l}{\left[37^{*}\right],\left[38^{*}\right],[39],[4} \\
0]\end{array}$ & & \\
\hline \multirow{2}{*}{$\begin{array}{l}\text { Local } \\
\text { Government } \\
\text { official }\end{array}$} & Transport & {$[32],[36]$,} & & [32], [36], & & & & [32] \\
\hline & Public Transport & [33], [34], & & [33], [34], & & & & \\
\hline \multirow{3}{*}{$\begin{array}{l}\text { Operator } \\
\text { Equipment } \\
\text { provider }\end{array}$} & Public Transport & [5], [18], & [5] & [5] & & & & \\
\hline & New modes & [48] & [48] & {$\left[27^{*}\right],[28],[48]$} & {$\left[27^{*}\right],[28]$} & & {$[27 *]$} & {$\left[27^{*}\right]$} \\
\hline & Planning etc & & & & & & [24] & \\
\hline \multirow[b]{5}{*}{ Lobbyist } & Transport & [19], & & [19], & & & & \\
\hline & Public Transport & {$[41],[50]$} & [50] & {$[41],[50]$} & {$\left[15^{*}\right],[41]$} & {$\left[15^{*}\right]$} & [50] & \\
\hline & Planning etc & [45], & & [45], & & [45] & & \\
\hline & Green & [25], & & {$[4]$} & & & [45] & \\
\hline & New modes & [26], & & [26], & & & & [26] \\
\hline \multirow[t]{2}{*}{ Observer } & Transport & $\begin{array}{l}{[6],[7],[8],[9],} \\
{[10],[11],[12],} \\
{[13],[16],[17],} \\
{[20],[29],[30],} \\
{[31],[49]}\end{array}$ & $\begin{array}{l}{[9],[10,[12],[13],[} \\
16],[29]\end{array}$ & $\begin{array}{l}{[6],[7],[8],[11],} \\
{[12],[13],[17],} \\
{[20],[29],[30],} \\
{[31],[49]}\end{array}$ & {$[20],[29]$} & {$[17],[49]$} & & {$[7],[1$} \\
\hline & Responses & 42 & 10 & 38 & 10 & 9 & 7 & 7 \\
\hline
\end{tabular}

NOTE: * denotes a female interviewee, and italic script denotes an international interviewee. 
Table 6: The user interface of the future by interviewee type

\begin{tabular}{|c|c|c|c|c|c|c|}
\hline Role & Sector & $\begin{array}{l}\text { Low Friction } \\
\text { Ticketing }\end{array}$ & $\begin{array}{l}\text { Differentiated } \\
\text { Ticketing }\end{array}$ & $\begin{array}{l}\text { Information by } \\
\text { Personal Device }\end{array}$ & $\begin{array}{l}\text { Pro-active } \\
\text { Journey } \\
\text { Information }\end{array}$ & $\begin{array}{l}\text { Disappearing } \\
\text { Timetables }\end{array}$ \\
\hline \multirow{3}{*}{$\begin{array}{l}\text { National } \\
\text { Government } \\
\text { official }\end{array}$} & Transport & {$[2],[3],[22],[23]$} & $\begin{array}{l}{[1],[2],[3],[22],} \\
{[23]}\end{array}$ & {$[1],[3],[21],[22]$} & [1] & {$[2]$} \\
\hline & Public Transport & $\begin{array}{l}{[35],\left[43^{*}\right],\left[46^{*}\right],} \\
{[47]}\end{array}$ & $\begin{array}{l}{[35],[44],\left[46^{*}\right],} \\
{[47]}\end{array}$ & {$\left[46^{*}\right]$} & {$\left[46^{*}\right]$} & [35] \\
\hline & Planning etc & {$\left[37^{*}\right],\left[38^{*}\right],[40]$,} & $\begin{array}{l}{\left[37^{*}\right],\left[38^{*}\right],[39],} \\
{[40],}\end{array}$ & {$\left[38^{*}\right],[39]$} & [39] & {$[37 *]$} \\
\hline \multirow{2}{*}{$\begin{array}{l}\text { Local } \\
\text { Government } \\
\text { official }\end{array}$} & Transport & [32], [36], & [36], & & & \\
\hline & Public Transport & [33], [34], & [33] & [33], [34], & [33], [34], & {$[34]$} \\
\hline \multirow[b]{2}{*}{ Operator } & Public Transport & [5], [18], & [5], [18], & [18], & & {$[18]$} \\
\hline & New modes & {$\left[27^{*}\right],[28],[48]$} & {$\left[27^{*}\right],[28]$} & {$\left[27^{*}\right]$} & {$\left[27^{*}\right],[48]$} & \\
\hline $\begin{array}{l}\text { Equipment } \\
\text { provider }\end{array}$ & Planning etc & [24], & [24], & [24], & [24] & \\
\hline \multirow[b]{5}{*}{ Lobbyist } & Transport & & [19], & [19], & & {$[19]$} \\
\hline & Public Transport & {$\left[15^{*}\right],[41],[50]$} & {$[50]$} & {$\left[15^{*}\right],[50]$} & {$\left[15^{*}\right]$} & \\
\hline & Planning etc & [45], & [45], & & & {$[45]$} \\
\hline & Green & [4], [25], & [4], [25], & [4], [25], & [4] & {$[4]$} \\
\hline & New modes & [26], & [26], & [26], & & {$[26]$} \\
\hline \multirow[t]{2}{*}{ Observer } & Transport & $\begin{array}{l}{[7],[8],[10],[11],} \\
{[12],[14],[16],} \\
{[17],[20],[29],} \\
{[49]}\end{array}$ & $\begin{array}{l}{[6],[7],[8],[9],} \\
{[11],[12],[13],} \\
{[16],[20],[30],} \\
{[31],[49]}\end{array}$ & $\begin{array}{l}{[6],[7],[8],[10],} \\
{[11],[12],[14],} \\
{[16],[20],[31],} \\
{[49]}\end{array}$ & $\begin{array}{l}{[6],[7],[14],[31],} \\
{[49]}\end{array}$ & $\begin{array}{l}{[7],[17],[20],} \\
{[31],[49]}\end{array}$ \\
\hline & Responses & 39 & 38 & 29 & 15 & \\
\hline
\end{tabular}

NOTE: * denotes a female interviewee, and italic script denotes an international interviewee. 
Table 7: Future service delivery mechanisms by interviewee type

\begin{tabular}{|c|c|c|c|c|c|c|}
\hline Role & Sector & $\begin{array}{l}\text { More Flexibly } \\
\text { Routed Services }\end{array}$ & $\begin{array}{l}\text { More On Demand } \\
\text { Services }\end{array}$ & $\begin{array}{l}\text { Point-to-Point } \\
\text { Predominant }\end{array}$ & $\begin{array}{l}\text { Point-to-Point } \\
\text { More Important }\end{array}$ & $\begin{array}{l}\text { Hub-and-Spol } \\
\text { More Importa }\end{array}$ \\
\hline \multirow{3}{*}{$\begin{array}{l}\text { National } \\
\text { Government } \\
\text { official }\end{array}$} & Transport & {$[2],[3],[22],[23]$} & {$[2],[22],[23]$} & {$[1],[2],[23]$} & [22] & {$[2],[23]$} \\
\hline & Public Transport & {$[35],\left[43^{*}\right],[47]$} & {$[35],\left[43^{*}\right],[47]$} & {$\left[42^{*}\right],\left[43^{*}\right],\left[46^{*}\right]$} & [35] & $\begin{array}{l}{\left[42^{*}\right],\left[43^{*}\right],} \\
{\left[46^{*}\right],[47]}\end{array}$ \\
\hline & Planning etc & [39], [40], & [39], [40], & {$\left[37^{*}\right],\left[38^{*}\right],[40]$,} & & {$\left[37^{*}\right],\left[38^{*}\right],[<$} \\
\hline \multirow{2}{*}{$\begin{array}{l}\text { Local } \\
\text { Government } \\
\text { official }\end{array}$} & Transport & [36], & [36], & [32], [36], & & {$[32],[36]$} \\
\hline & Public Transport & & & & [33] & \\
\hline \multirow[b]{2}{*}{ Operator } & Public Transport & [5], [18], & [18], & & [18] & [18] \\
\hline & New modes & [48] & [48] & [48] & {$\left[27^{*}\right]$} & \\
\hline $\begin{array}{l}\text { Equipment } \\
\text { provider }\end{array}$ & Planning etc & & & & & \\
\hline \multirow[b]{5}{*}{ Lobbyist } & Transport & [19], & [19], & & [19] & \\
\hline & Public Transport & {$\left[15^{*}\right],[50]$} & {$\left[15^{*}\right],[50]$} & {$[41],[50]$} & [50] & [41] \\
\hline & Planning etc & [45], & [45], & [45], & & [45] \\
\hline & Green & [4], & [4], & [25], & & [25] \\
\hline & New modes & & & & [26] & \\
\hline \multirow[t]{2}{*}{ Observer } & Transport & $\begin{array}{l}{[6],[7],[8],[9],} \\
{[11],[14],[16],} \\
{[17],[20],[29],} \\
{[30],[49]}\end{array}$ & $\begin{array}{l}{[6],[7],[8],[9],} \\
{[11],[14],[16],} \\
{[17],[20],[29],} \\
{[30],[49]}\end{array}$ & {$[[7],[8],[12],[16]$} & $\begin{array}{l}{[9],[11],[14],} \\
{[20],[29],[30],} \\
{[49]}\end{array}$ & $\begin{array}{l}{[7],[8],[12],[} \\
{[29]}\end{array}$ \\
\hline & Responses & 30 & 28 & 20 & 15 & \\
\hline
\end{tabular}

NOTE: * denotes a female interviewee, and italic script denotes an international interviewee. 
Table 8: The future operational environment by interviewee type

\begin{tabular}{|c|c|c|c|c|c|}
\hline Role & Sector & $\begin{array}{l}\text { Private Sector } \\
\text { Dominates }\end{array}$ & $\begin{array}{l}\text { Very Large Private } \\
\text { Company } \\
\text { Involvement }\end{array}$ & $\begin{array}{l}\text { More Smaller, } \\
\text { Community, Public } \\
\text { Sector Operators }\end{array}$ & $\begin{array}{l}\text { Complex Mix of } \\
\text { Operators }\end{array}$ \\
\hline National & Transport & {$[1],[2],[3]$} & [1] & & $\begin{array}{l}{[35],\left[42^{*}\right],[44],} \\
{[47]}\end{array}$ \\
\hline \multirow{2}{*}{$\begin{array}{l}\text { Government } \\
\text { official }\end{array}$} & Public Transport & {$\left[46^{*}\right],[47]$} & {$\left[43^{*}\right],[44],[47]$} & {$\left[42^{*}\right],[35]$} & {$\left[37^{*}\right],[40]$} \\
\hline & Planning etc & {$\left[38^{*}\right],[40]$} & [39] & {$\left[37^{*}\right],[40]$} & \\
\hline Local & Transport & [36] & & [36] & \\
\hline $\begin{array}{l}\text { Government } \\
\text { official }\end{array}$ & Public Transport & & & & \\
\hline \multirow{3}{*}{\begin{tabular}{|l|} 
Operator \\
Equipment \\
provider
\end{tabular}} & Public Transport & [5], & & & \\
\hline & New modes & [28] & & {$[28],[48]$} & [48] \\
\hline & Planning etc & & & & \\
\hline \multirow[b]{5}{*}{ Lobbyist } & Transport & [19], & [19] & & [19] \\
\hline & Public Transport & {$\left[15^{*}\right]$} & & & [50] \\
\hline & Planning etc & & & & \\
\hline & Green & [4] & & & \\
\hline & New modes & & & & \\
\hline Observer & Transport & $\begin{array}{l}{[7],[8],[9],[11],} \\
{[12],[13],[14],} \\
{[29],[30],[31]}\end{array}$ & $\begin{array}{l}{[8],[10],[11],} \\
{[29],[49]}\end{array}$ & $\begin{array}{l}{[6],[10],[11],} \\
{[12],[20],[30],} \\
{[49]}\end{array}$ & $\begin{array}{l}{[12],[16],[17],} \\
{[30],[49]}\end{array}$ \\
\hline
\end{tabular}

NOTE: * denotes a female interviewee, and italic script denotes an international interviewee. 